\title{
Garden post-transplant effects of pre-transplant plug cell volume and growing medium quality (as abiotic stresses) in Impatiens walleriana
}

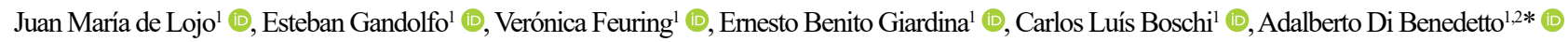 \\ ${ }^{1}$ University of Buenos Aires, Faculty of Agronomy, Buenos Aires, Argentina. \\ ${ }^{2}$ National University of Mar del Plata, Faculty of Agricultural Sciences, Balcarce, Province of Buenos Aires, Argentina.
}

\begin{abstract}
Although much is known about the production of bedding plants, including Impatiens walleriana, little has been documented on their post-production performance. Thus, the aim of this work was to understand how pre-transplant crop management related to root restrictions imposed by plug cell volume and substrate quality affects the post-production performance related to biomass accumulation. To this end, we tested four plug cell volumes, as well as four growing media with significantly different physical and chemical properties, during nursery and pot culture. We also evaluated the difference between use and nonuse of synthetic cytokinin spray (benzyl aminopurine, BAP), a proven stress alleviator. Our novelty data validated the previous hypothesis and showed that plant quality and garden performance are dependent on these potential stress sources. The physiological mechanisms involved included differences in leaf area expansion (estimated mainly by relative leaf area expansion rate) and differences in $\mathrm{CO}_{2}$ fixation capacity (estimated by net assimilation rate). The sum of these responses determined significant differences in total fresh and dry weight during pot culture, which were amplified when plants were transplanted to a field bed. Spraying plants with synthetic cytokinin early during nursery allowed overriding of most root restriction abiotic stresses related to plug cell volume and growing media; therefore, synthetic cytokinin constitutes a tool to improve the yield of bedding plants (at the grower's level) and garden performance.
\end{abstract}

Keywords: bedding plants; field performance; growth analysis; nursery.

\section{Resumo}

Desenvolvimento pós-plantio de Impatiens walleriana influenciada pelo volume de recipiente, qualidade do substrato e aplicação de citocinina na fase de produção da muda

Trabalhos testando fatores de produção de mudas em Impatiens walleriana são relatados, mas pouco se sabe sobre a influência dos fatores testados no seu desenvolvimento depois do plantio no jardim. Assim, o objetivo deste trabalho foi compreender como o manejo da cultura na produção da muda, relacionado às restrições radiculares impostas pelo volume de recipiente e a qualidade do substrato, afeta o desempenho pós-produção relacionado ao acúmulo de biomassa. Para tanto, testamos quatro volumes de recipientes, quatro substratos para plantas com propriedades físicas e químicas significativamente diferentes, durante a fase de sementeira e depois na fase de viveiro, e o uso ou não de citocinina (benzil aminopurina, BAP). Os mecanismos fisiológicos envolvidos incluíram diferenças na expansão da área foliar (estimada principalmente por meio da taxa de expansão da área foliar relativa) e diferenças na capacidade de fixação de $\mathrm{CO}_{2}$ (estimada por meio da taxa de assimilação líquida). A soma dessas respostas determinou diferenças significativas no peso fresco e seco total durante a cultura em recipientes, amplificadas quando as plantas foram transplantadas para o jardim. A aplicação de citocinina permitiu anular a maioria dos estresses abióticos relacionados à restrição de volume de substrato disponível para o desenvolvimento radicular e, portanto, representa uma ferramenta para melhorar o desenvolvimento das plantas no viveiro e o desempenho do jardim.

Palavras-chave: plantas anuais; performance de campo; análise de crescimento; viveiro.

\section{Introduction}

Bedding plants represent the fastest growing segment of the Green Industries. Annual sales of flowering potted plants keep setting new records, as their popularity continues to soar among consumers of most developed and developing countries. One of the most important and most widely grown bedding plants in the world today is Impatiens walleriana Hook. f., commonly known as "buzzy Lizzy", "patience plant" or "balsamine" (Uchneat, 2007). The species is native

*Corresponding author: dibenede@agro.uba.ar 
to the cool and rainy countries of Southeast Asia, tropical Africa, Madagascar, south of India, east of Himalaya and Sri Lanka (Rahelivololona et al., 2018).

Since the ultimate destination of bedding plants is a garden setting, understanding their physiological responses during the post-production stage becomes very important to preserve their quality. Although much is known about the production of bedding plants, little has been documented recently on their post-production performance (Hakim et al., 2017). At certain times during the production cycle, decisions influencing longevity need to be made. At the end of the production phase, for example, several specific actions can be executed in order to increase shelf life. In contrast, any practice that decreases plant quality during production also decreases shelf life, and, regardless of the causes, a plant suffering stress has a reduced shelf life. If plants leaving the greenhouse have poor quality, then the best of places will not be able to improve their postproduction life (Armitage, 1986).

The quality of flowering bedding plants is essentially defined by their visual appearance. One of the main criteria to evaluate the visual quality of an ornamental potted plant is its shape: many of them should be compact and well branched (Bergstrand, 2017). However, the quality of ornamental plants can also be appraised with other criteria, including tolerance to biotic and abiotic stresses, development potentialities and aesthetics. In this way, horticulturists are faced with the challenge of defining the quality of plants in terms of aesthetic criteria, stress resistance, longevity and aftersales development (Ferrante et al., 2015).

Technological advances in transplanting have contributed to the expansion of the bedding plant industry and to the possibility of offering the best plants at the lowest price. Bedding plant growers have historically chosen the best growing media (Barrett et al., 2016) and best greenhouse environment, although significant changes in order to decrease costs have been recently proposed. Commercial profits have been related to a decrease in plug cell volume and the use of less expensive growing media. Pot bedding plant growers must make two critical technological decisions: pre-transplant plug cell size and pre and post-transplant growing medium, both of which have been previously mentioned as abiotic stress sources (Di Benedetto et al., 2020) in several bedding plants, including I. walleriana (De Lojo et al., 2017, 2019a, 2019b). These business choices imply that plants will suffer different root restriction stresses during most of their growing cycle.

Ornamental pot plant productivity is related to the environmental conditions and negatively affected by pot root restriction syndrome during both the nursery and posttransplant stage (Di Benedetto et al., 2020). Plant roots can sense adverse soil conditions and, via some internal signal, transmit the condition of the soil to the extending leaves, with the typically net result of a decrease in leaf elongation rates and photosynthesis (Zakaria et al., 2020). The understanding of the response of ornamental bedding plants to short and long-term stresses such as the root restriction imposed by small plug cell trays or growing medium quality is limited by the interactions of plants with these stresses. On the assumption that the responses are mainly associated with a negative hormonal signaling from roots, a pre-transplant benzyl aminopurine (BAP) spray has been suggested in order to override these abiotic stresses in I. walleriana and other pot bedding plants (De Lojo et al., 2017, 2019a, 2019b; Hakim et al., 2017; Di Benedetto et al., 2020).

The aim of this work was to evaluate the field postproduction performance of I. walleriana after the pot growth stage in four different plug cell volumes during nursery and four pre or post-transplant growing media with different physical properties, during both nursery and pot culture.

\section{Materials and Methods}

The experiment was conducted in a greenhouse at the School of Agronomy, University of Buenos Aires, Argentina (343' $59^{\prime}$ 'S, $58^{\circ} 22^{\prime} 23^{\prime}$ 'W), from October $10^{\text {th }}$, 2016, to March $9^{\text {th }}, 2017$, and was repeated from October $16^{\text {th }}, 2017$, to March $15^{\text {th }}, 2018$.

Impatiens walleriana 'Xtreme White' seeds (Goldsmith Inc., NY, USA) were germinated and grown in 50-, 128-, 288and 512-cell plug tray-1 $\left(55.70,17.37,6.18\right.$ and $2.50 \mathrm{~cm}^{3}$ cell- $^{-1}$, respectively), in four different pre-transplant growing media:

- Klasmann $411^{\circledR}$ medium (Klasmann-Deilmann, GmbH, Germany): Canadian Sphagnum peat moss-perlitevermiculite $(70 / 20 / 10 \mathrm{v} / \mathrm{v} / \mathrm{v})(\mathrm{K})$;

- Sphagnum maguellanicum-perlite (80/20 v/v) (S);

- River waste-perlite (80-20 v/v) (R);

- Sphagnum maguellanicum-river waste-perlite (40-4020, v/v/v) (SR).

Samples of each substrate and of the field soil were collected at the beginning of the pot experiments (before transplant to $1,200-\mathrm{cm}^{3}$ pots) and total porosity, airfilled porosity, bulk density and container capacity were determined according to Fonteno (1996) (Table 1).

Table 1. Physical properties of the growing media tested. K: [Canadian Sphagnum peat (70\%) + Perlite (20\%) + Vermiculite (10\%)], S: [Sphagnum maguellanicum (80\%) + Perlite (20\%)], R: [River waste (80\%) + Perlite (20\%)], SR: [Sphagnum maguellanicum $(40 \%)+$ River waste $(40 \%)+$ perlite $(20 \%)]$. Standard errors are indicated.

\begin{tabular}{|l|c|c|c|c|}
\hline Growing media & Total porosity (\%) & Air-filled porosity (\%) & Bulk density (g dm $\left.\mathbf{~}^{-3}\right)$ & Container capacity (\%) \\
\hline K & $60.00 \pm 0.55$ & $12.93 \pm 0.98$ & $0.21 \pm 0.04$ & $36.89 \pm 1.46$ \\
\hline S & $70.67 \pm 0.67$ & $29.67 \pm 2.15$ & $0.15 \pm 0.01$ & $48.00 \pm 0.38$ \\
\hline R & $72.67 \pm 0.18$ & $44.60 \pm 0.95$ & $0.18 \pm 0.01$ & $50.22 \pm 0.44$ \\
\hline SR & $67.53 \pm 0.64$ & $23.27 \pm 2.43$ & $0.21 \pm 0.01$ & $42.67 \pm 0.38$ \\
\hline Field soil & $25.02 \pm 0.34$ & $5.60 \pm 1.21$ & $0.90 \pm 0.10$ & $31.56 \pm 2.25$ \\
\hline
\end{tabular}


During nursery, leaves were sprayed at sunset with 0 or $100 \mathrm{mg} \mathrm{L}^{-1}$ BAP solutions (about $5 \mathrm{~m}^{2}$ benches liter ${ }^{-1}$ ), when the first true leaf pair was developed. The BAP concentration was chosen from previous experiments performed between 2010 and 2011 (Di Benedetto and Pagani, 2013).

When seedlings reached the transplant stage, they were transplanted into $1,200-\mathrm{cm}^{3}$ pots filled with post-transplant Klasmann $411^{\circledR}$ medium (Klasmann-Deilmann, GmbH, Germany). At the same time, plants grown at the pretransplant stage in Klasmann $411^{\circledR}$ medium (KlasmannDeilmann, GmbH, Germany) were transplanted to 1,200$\mathrm{cm}^{3}$ pots filled with the four different pre-transplant growing media tested, resulting in a total of 32 combinations of plug cell volume-growing media-BAP applications. After 60 days of greenhouse cropping, plants were transplanted to a field soil until the end of the experiment.

Plants were irrigated daily at saturation (watering was added each time as far as a fine water layer appeared on the substrate surface) with high quality tap water, using intermittent overhead mist. The growing media were fertilized weekly with 1.0: 0.5: 1.0: $0.5(\mathrm{v} / \mathrm{v} / \mathrm{v} / \mathrm{v}) \mathrm{N}: \mathrm{P}$ : $\mathrm{K}$ : Ca via overhead irrigation water, according to Styer and Koranski (1997): stage 2 (from radicle emergence to formation of cotyledonary leaves): $50 \mathrm{mg} \mathrm{L}^{-1} \mathrm{~N}$; stage 3 (development of true leaves): $100 \mathrm{mg} \mathrm{L}^{-1} \mathrm{~N}$; stage 4 (the finishing or hardening stage): $100 \mathrm{mg} \mathrm{L}^{-1} \mathrm{~N}$; pot culture (from transplant to sale): $150 \mathrm{mg} \mathrm{L}^{-1} \mathrm{~N}$.

Daily mean temperatures $\left(22.26\right.$ to $\left.25.06^{\circ} \mathrm{C}\right)$ and daily photosynthetic active radiation (4.24 to $5.03 \mathrm{~mol}$ photons $\mathrm{m}^{-2}$ day $^{-1}$ ) for the experiments were recorded with a HOBO sensor (H08-004-02) (Onset Computer Corporation, MA, USA), connected to a HOBO H8 data logger. The plants were arranged at a density of 25 plants $\mathrm{m}^{-2}$, which prevented mutual shading.

Plants were harvested at the transplant stage and at 15 , 30,45 , and 60 days after transplanting. Roots were washed, and root, stem and leaf fresh weights (FW) were recorded. Dry weights (DW) were obtained after drying roots, stems and leaves to constant weight at $80^{\circ} \mathrm{C}$ for 96 hours. The number of leaves was recorded, and each leaf's area was determined using the Image ${ }^{\circledR}$ (Image Processing and Analysis in Java) software. The number of stems, nodes and flowers was recorded as well.

The relative rate of leaf area expansion (RLAE) was calculated as the slope of the regression of the natural logarithm (ln) of total leaf area versus time (in days). The specific leaf area on a FW basis (SLA) and leaf weight rate (LWR) were calculated as the ratio between the area of the new individual leaf and leaf FW, and the ratio between the leaf DW and the total plant DW, respectively, at the end of the experiments. The relative growth rate (RGR) was calculated as the slope of the regression of the ln of whole plant DW versus time (in days). The mean net assimilation rate (NAR) and the root: shoot ratio (at the end of the experiments) were also determined.

The content of reducing sugars in each plant organ (roots, shoots and leaves) was analysed in the final sampling of the pot experiments, using the Nelson-Somogyi method.
The experimental design was a randomized factorial with three blocks of five single-pot replications of each treatment combination (plug cell volume $\times$ growing medium $\times$ BAP concentration). Since there were no significant differences between the two experiments, they were considered together. Data was subjected to three-way analysis of variance (ANOVA). The STATISTICA 8 (StatSoft) software was used and the assumptions of the ANOVA were checked. Means were separated by Tukey's tests $(\mathrm{P} \leq 0.05)$. When applicable, Fisher's LSD-test $(\mathrm{P}<0.05)$ was applied to determine the direction of the differences between treatment mean values. Slopes from straight-line regressions of RLAE and RGR were tested using the SMATR package.

\section{Results and Discussion}

At the end of the pot experiment (60 days), total leaf area, total FW and total DW were the highest in plants from 50plug cell tray ${ }^{-1}$, and decreased as the number of cells tray ${ }^{-1}$ increased. The growing media significantly changed the three growth parameters recorded. In most treatments, the highest values were found in plants grown in $\mathrm{R}$ and $\mathrm{S}$, while the lowest ones were found in plants grown in K. A single BAP spray applied at the moment the first true leaf pair was developed significantly increased the responses to the plug cell volume and the growing media (Table 2). The changes in leaf area, FW and DW were different depending on the growing medium used during the pot stage (Table 3).

When seedlings are grown in typical transplant containers, growth (roots and stems) tends to be proportional to the volume of the container cell (Di Benedetto et al., 2020). The bigger the space available to the plant from the nursery stage, the larger the plant becomes after transplant, and the more quickly it attains particular growth stages (Table 2). These results are in agreement with Di Benedetto et al. (2020), who suggested that root restriction significantly decreased photosynthetic capacity and change photo assimilate partitioning. In contrast with some of the previous reports here described, which indicated that the plug cell size is the main abiotic stress during nursery, the quality of the growing medium would be a more restrictive abiotic stress at that growth stage than previously supposed (Table 2 versus Table 3 ), in agreement with that found in De Lojo et al. (2019a).

The use of different plug cell volumes during nursery, different growing media at both nursery and pot cropping, and a single BAP spray at nursery allowed the obtainment of a high number of plants with different shapes and physiological performance previous to transplant to the field (Tables 2 and 3). The shape of I. walleriana at the beginning of the field experiment was in agreement with previous results from our laboratory (Di Benedetto et al., 2020).

Total leaf area at the end of the field experiment was the highest in plants from 50-plug cell tray ${ }^{-1}$ and decreased as the number of cells tray ${ }^{-1}$ increased, in all growing media tested. The growing medium quality during nursery had a significant effect on leaf area expansion 60 days after field growth. The early BAP spray significantly increased total leaf area at the end of the field experiment. However, the 
Table 2. Mean total leaf area, fresh weight and dry weight at the field transplant stage for Impatiens walleriana plants from four plug cell volumes (50-, 128-, 288-, and 512-cell tray $\left.{ }^{-1}\right)$, four growing media at nursery and sprayed with zero (control plants) or $100 \mathrm{mg} \mathrm{L}^{-1}$ BAP during nursery. Different lowercase letters indicate significant differences $(\mathrm{p}<0.05)$ between control and BAP-sprayed plants, while different capital letters indicate significant differences $(p<0.05)$ between pre-transplant plug cell volumes. For substrate abbreviations, see Table 1.

\begin{tabular}{|c|c|c|c|c|c|c|}
\hline & \multicolumn{2}{|c|}{ Total leaf area $\left(\mathrm{cm}^{2}\right.$ plant $\left.^{-1}\right)$} & \multicolumn{2}{|c|}{ Fresh weight (g plant $\left.{ }^{-1}\right)$} & \multicolumn{2}{|c|}{ Dry weight (g plant $\left.{ }^{-1}\right)$} \\
\hline & Control & BAP & Control & BAP & Control & BAP \\
\hline \multicolumn{7}{|l|}{ K } \\
\hline 50 & $71.66^{\mathrm{aD}}$ & $86.63^{\mathrm{aD}}$ & $20.89^{\mathrm{aD}}$ & $27.50^{\mathrm{aC}}$ & $1.89^{\mathrm{aC}}$ & $1.70^{\mathrm{aD}}$ \\
\hline 128 & $58.83^{\mathrm{bD}}$ & $77.67^{\mathrm{bD}}$ & $14.55^{\mathrm{bD}}$ & $24.30^{\mathrm{bC}}$ & $1.45^{\mathrm{bB}}$ & $1.64^{\mathrm{abC}}$ \\
\hline 288 & $53.28^{\mathrm{bD}}$ & $73.68^{\mathrm{bD}}$ & $13.52^{\mathrm{bC}}$ & $22.85^{\text {bD }}$ & $1.19^{\mathrm{cC}}$ & $1.57^{\mathrm{bC}}$ \\
\hline 512 & $46.89^{\mathrm{cC}}$ & $66.58^{\mathrm{cD}}$ & $11.07^{\mathrm{cD}}$ & $18.78^{\mathrm{cC}}$ & $1.08^{\mathrm{dC}}$ & $0.94^{\mathrm{cD}}$ \\
\hline \multicolumn{7}{|l|}{ S } \\
\hline 50 & $137.27^{\mathrm{aB}}$ & $140.26^{\mathrm{aB}}$ & $44.56^{\mathrm{aB}}$ & $50.39^{\mathrm{aB}}$ & $1.42^{\mathrm{aD}}$ & $2.61^{\mathrm{aC}}$ \\
\hline 128 & $124.52^{\mathrm{bB}}$ & $136.26^{\mathrm{aB}}$ & $38.18^{\mathrm{bB}}$ & $47.09^{\mathrm{aB}}$ & $1.28^{\mathrm{bC}}$ & $2.44^{\mathrm{bD}}$ \\
\hline 288 & $112.93^{\mathrm{cB}}$ & $134.64^{\mathrm{abB}}$ & $30.20^{\mathrm{cB}}$ & $44.90^{\mathrm{bB}}$ & $1.21^{\mathrm{bC}}$ & $2.08^{\mathrm{cB}}$ \\
\hline 512 & $87.30^{\mathrm{dA}}$ & $117.47^{\mathrm{bA}}$ & $22.28^{\mathrm{dC}}$ & $42.29^{\mathrm{bA}}$ & $0.96^{\mathrm{cD}}$ & $1.48^{\mathrm{dC}}$ \\
\hline \multicolumn{7}{|l|}{$\mathrm{R}$} \\
\hline 50 & $172.15^{\mathrm{aA}}$ & $169.59^{\mathrm{aA}}$ & $51.59^{\mathrm{aA}}$ & $66.33^{\mathrm{aA}}$ & $2.16^{\mathrm{aB}}$ & $3.40^{\mathrm{aA}}$ \\
\hline 128 & $160.27^{\mathrm{bA}}$ & $159.96^{\mathrm{bA}}$ & $48.96^{\mathrm{aA}}$ & $60.31^{\mathrm{bA}}$ & $2.05^{\mathrm{bA}}$ & $3.15^{\mathrm{bA}}$ \\
\hline 288 & $121.22^{\mathrm{cA}}$ & $154.50^{\mathrm{bA}}$ & $36.71^{\mathrm{bA}}$ & $54.79^{\mathrm{cA}}$ & $1.95^{\mathrm{cA}}$ & $2.67^{\mathrm{cA}}$ \\
\hline 512 & $87.85^{\mathrm{dA}}$ & $93.78^{\mathrm{cC}}$ & $32.72^{\mathrm{bA}}$ & $34.04^{\mathrm{dB}}$ & $1.82^{\mathrm{cA}}$ & $1.76^{\mathrm{dA}}$ \\
\hline \multicolumn{7}{|l|}{ SR } \\
\hline 50 & $109.50^{\mathrm{aC}}$ & $123.15^{\mathrm{aC}}$ & $33.76^{\mathrm{aC}}$ & $57.89^{\mathrm{aB}}$ & $2.50^{\mathrm{aA}}$ & $2.73^{\mathrm{aB}}$ \\
\hline 128 & $94.77^{\mathrm{bC}}$ & $117.61^{\mathrm{aC}}$ & $33.31^{\mathrm{aC}}$ & $42.13^{\mathrm{bB}}$ & $2.02^{\mathrm{bA}}$ & $2.57^{\mathrm{aB}}$ \\
\hline 288 & $75.21^{\mathrm{cC}}$ & $109.55^{\mathrm{bC}}$ & $33.18^{\mathrm{aB}}$ & $33.87^{\mathrm{cC}}$ & $1.72^{\mathrm{cB}}$ & $1.64^{\mathrm{bC}}$ \\
\hline 512 & $69.97^{\mathrm{dB}}$ & $106.94^{\mathrm{bB}}$ & $26.98^{\mathrm{bB}}$ & $33.07^{\mathrm{cB}}$ & $1.40^{\mathrm{dB}}$ & $1.63^{\mathrm{bB}}$ \\
\hline
\end{tabular}

Table 3. Mean total leaf area, fresh weight and dry weight at the field transplant stage for Impatiens walleriana plants from four plug cell volumes (50-, 128-, 288-, and 512-cell tray $\left.{ }^{-1}\right)$, four growing media at the pot stage and sprayed with zero (control plants) or $100 \mathrm{mg} \mathrm{L}^{-1}$ BAP during nursery. Different lowercase letters indicate significant differences $(p<0.05)$ between pre-transplant plug cell volumes, while different capital letters indicate significant differences $(p<0.05)$ between control and BAP-sprayed plants. For substrate abbreviations, see Table 1.

\begin{tabular}{|c|c|c|c|c|c|c|}
\hline & \multicolumn{2}{|c|}{ Total leaf area $\left(\mathrm{cm}^{2}\right.$ plant $\left.^{-1}\right)$} & \multicolumn{2}{|c|}{ Fresh weight (g plant $\left.{ }^{-1}\right)$} & \multicolumn{2}{|c|}{ Dry weight (g plant ${ }^{-1}$ ) } \\
\hline & Control & BAP & Control & BAP & Control & BAP \\
\hline \multicolumn{7}{|l|}{ K } \\
\hline 50 & $167.09^{\mathrm{aC}}$ & $316.33^{\mathrm{aB}}$ & $64.53^{\mathrm{aA}}$ & $123.75^{\mathrm{aA}}$ & $3.85^{\mathrm{aA}}$ & $6.62^{\mathrm{aA}}$ \\
\hline 128 & $152.45^{\mathrm{bA}}$ & $236.69^{\mathrm{bA}}$ & $58.11^{\mathrm{bA}}$ & $89.92^{\mathrm{bA}}$ & $3.39^{\mathrm{aA}}$ & $5.26^{\mathrm{bA}}$ \\
\hline 288 & $140.65^{\mathrm{cA}}$ & $196.03^{\mathrm{cB}}$ & $53.44^{\mathrm{bA}}$ & $73.68^{\mathrm{cA}}$ & $3.23^{\mathrm{aA}}$ & $3.34^{\mathrm{cB}}$ \\
\hline 512 & $102.12^{\mathrm{dB}}$ & $167.76^{\mathrm{dB}}$ & $42.96^{\mathrm{cA}}$ & $55.18^{\mathrm{dA}}$ & $2.58^{\mathrm{bA}}$ & $2.99^{\mathrm{dA}}$ \\
\hline \multicolumn{7}{|l|}{ S } \\
\hline 50 & $115.95^{\mathrm{aD}}$ & $201.95^{\mathrm{aD}}$ & $66.29^{\mathrm{aA}}$ & $63.49^{\mathrm{aC}}$ & $1.83^{\mathrm{aB}}$ & $2.97^{\mathrm{aD}}$ \\
\hline 128 & $95.71^{\mathrm{bD}}$ & $149.65^{\mathrm{bD}}$ & $52.48^{\mathrm{bB}}$ & $48.69^{\mathrm{bC}}$ & $1.80^{\mathrm{aB}}$ & $2.17^{\mathrm{bD}}$ \\
\hline 288 & $92.42^{\mathrm{bC}}$ & $142.52^{\mathrm{bC}}$ & $29.07^{\mathrm{cB}}$ & $37.59^{\mathrm{cC}}$ & $1.38^{\mathrm{bD}}$ & $1.74^{\mathrm{cD}}$ \\
\hline 512 & $73.74^{\mathrm{cC}}$ & $131.34^{\mathrm{cC}}$ & $25.29^{\mathrm{cC}}$ & $33.61^{\mathrm{cB}}$ & $1.16^{\mathrm{bD}}$ & $1.59^{\mathrm{cD}}$ \\
\hline \multicolumn{7}{|l|}{$\mathrm{R}$} \\
\hline 50 & $189.95^{\mathrm{aB}}$ & $244.34^{\mathrm{aC}}$ & $66.29^{\mathrm{aA}}$ & $63.49^{\mathrm{aC}}$ & $3.85^{\mathrm{aA}}$ & $3.53^{\mathrm{aC}}$ \\
\hline 128 & $144.00^{\mathrm{bB}}$ & $161.07^{\mathrm{bC}}$ & $54.12^{\mathrm{bB}}$ & $52.12^{\mathrm{bC}}$ & $3.46^{\mathrm{aA}}$ & $3.16^{\mathrm{aB}}$ \\
\hline 288 & $132.16^{\mathrm{cA}}$ & $151.45^{\mathrm{cC}}$ & $31.82^{\mathrm{cB}}$ & $39.17^{\mathrm{cC}}$ & $1.75^{\mathrm{bC}}$ & $2.32^{\mathrm{bC}}$ \\
\hline 512 & $124.41^{\mathrm{dA}}$ & $133.47^{\mathrm{dC}}$ & $31.37^{\mathrm{cB}}$ & $39.07^{\mathrm{cB}}$ & $1.72^{\mathrm{bC}}$ & $2.14^{\mathrm{bC}}$ \\
\hline \multicolumn{7}{|l|}{ SR } \\
\hline 50 & $210.34^{\mathrm{aA}}$ & $341.55^{\mathrm{aA}}$ & $60.07^{\mathrm{aB}}$ & $97.73^{\mathrm{aB}}$ & $3.84^{\mathrm{aA}}$ & $4.94^{\mathrm{aB}}$ \\
\hline 128 & $130.38^{\mathrm{bC}}$ & $214.50^{\mathrm{bB}}$ & $34.42^{\mathrm{bC}}$ & $70.72^{\mathrm{bB}}$ & $2.30^{\mathrm{bB}}$ & $4.00^{\mathrm{bB}}$ \\
\hline 288 & $125.00^{\mathrm{cB}}$ & $208.42^{\mathrm{cA}}$ & $33.71^{\mathrm{bB}}$ & $64.71^{\mathrm{cB}}$ & $2.18^{\mathrm{bB}}$ & $3.72^{\mathrm{bA}}$ \\
\hline 512 & $121.41^{\mathrm{cA}}$ & $190.00^{\mathrm{dA}}$ & $33.07^{\mathrm{bB}}$ & $52.00^{\mathrm{dA}}$ & $2.07^{\mathrm{bB}}$ & $2.58^{\mathrm{cB}}$ \\
\hline
\end{tabular}


response of plants germinated in 50-plug cell tray ${ }^{-1}$ was quite lower than that of those germinated in the other plug cell volumes (Figure 1).

Regardless of the leaf area observed when plants were transplanted to the final field soil, the different leaf area expansions observed at the end of the experiment in the different nursery plug cell volumes or growing media tested were supported by the RLAE during the 60 days of the field experiment (Table 4).

The shelf life of a bedding plant during a field experiment would, then, be related to three traits: leaf area expansion, stem number and flower number (Di Benedetto et al.,

\section{-Control aBAP}

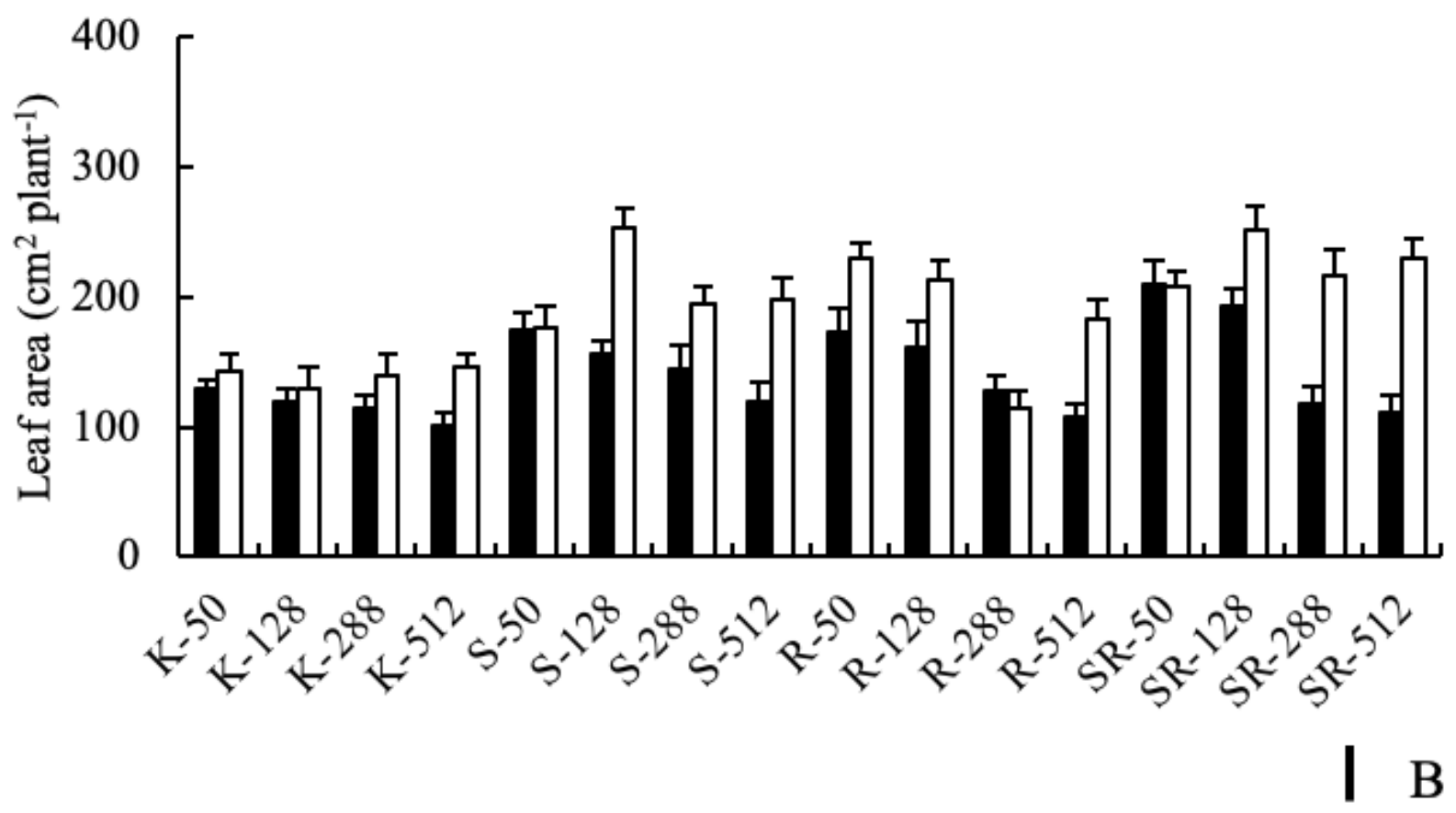

-Control aBAP

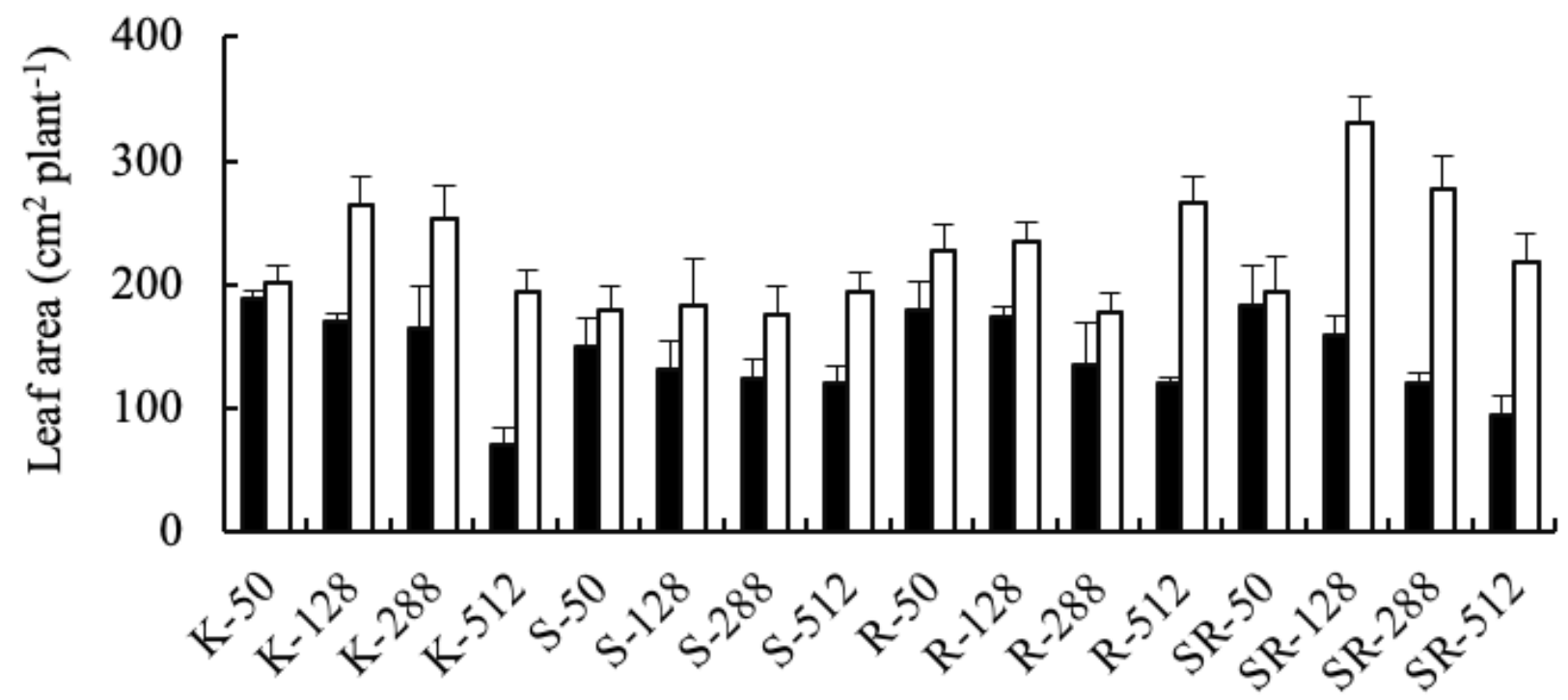

Figure 1. Total leaf area at the end of the field experiments (60 days after transplanting to a field bed) for Impatiens walleriana plants from four plug cell volumes (50-, 128-, 288-, and 512-cell tray $\left.{ }^{-1}\right)$, four growing media at (A) the nursery or (B) pot stage and sprayed with $100 \mathrm{mg} \mathrm{L}^{-1}$ BAP during nursery. The bars indicate standard errors and the vertical lines indicate least significant differences (LSD). For substrate abbreviations, see Table 1. 
2020). In our study, all these traits were positively related to the treatments tested (higher plug cell volume, specific growing media, and an exogenous cytokinin application).

Leaf area can be determined either in absolute terms

Table 4. Changes in rate of leaf area expansion (RLAE) during the field experiment for Impatiens walleriana plants from four plug cell volumes (50-, 128-, 288-, and 512-cell $\operatorname{tray}^{-1}$ ), four growing media at nursery or pot stage and sprayed with zero (control plants) or $100 \mathrm{mg} \mathrm{L}^{-1}$ BAP during nursery. Different lowercase letters indicate significant differences $(p<0.05)$ between pre-transplant plug cell volumes, while different capital letters indicate significant differences $(\mathrm{p}<0.05)$ between pre and post- growing media. For substrate abbreviations, see Table 1 . The probability of the RLAE slope being zero was $p<0.001$. Pre: between nursery and pot growth; Post: during the field experiment.

\begin{tabular}{|c|c|c|c|c|}
\hline & \multicolumn{4}{|c|}{ RLAE $\left(\mathrm{cm}^{2} \mathrm{~cm}^{-2}\right.$ day $\left.^{-1}\right)$} \\
\hline & Pre-Control & Pre-BAP & Post-Control & Post-BAP \\
\hline \multicolumn{5}{|l|}{ K } \\
\hline 50 & $0.0286^{\mathrm{aA}}$ & $0.0234^{\mathrm{cB}}$ & $0.0639^{\mathrm{aA}}$ & $0.0616^{\mathrm{aB}}$ \\
\hline 128 & $0.0282^{\mathrm{aA}}$ & $0.0279^{\mathrm{bA}}$ & $0.0635^{\mathrm{aA}}$ & $0.0622^{\mathrm{aB}}$ \\
\hline 288 & $0.0231^{\mathrm{bB}}$ & $0.0337^{\mathrm{aA}}$ & $0.0632^{\mathrm{aA}}$ & $0.0508^{\mathrm{bB}}$ \\
\hline 512 & $0.0223^{\mathrm{bB}}$ & $0.0333^{\mathrm{aA}}$ & $0.0606^{\mathrm{bA}}$ & $0.0620^{\mathrm{aA}}$ \\
\hline \multicolumn{5}{|l|}{$\mathrm{S}$} \\
\hline 50 & $0.0371^{\mathrm{aA}}$ & $0.0287^{\mathrm{dB}}$ & $0.0567^{\mathrm{aA}}$ & $0.0441^{\mathrm{cB}}$ \\
\hline 128 & $0.0363^{\mathrm{aA}}$ & $0.0333^{\mathrm{cB}}$ & $0.0570^{\mathrm{aA}}$ & $0.0543^{\mathrm{bB}}$ \\
\hline 288 & $0.0317^{\mathrm{bB}}$ & $0.0406^{\mathrm{aA}}$ & $0.0550^{\mathrm{bA}}$ & $0.0552^{\mathrm{bA}}$ \\
\hline 512 & $0.0280^{\mathrm{cB}}$ & $0.0377^{\mathrm{bA}}$ & $0.0444^{\mathrm{cB}}$ & $0.0677^{\mathrm{aA}}$ \\
\hline \multicolumn{5}{|l|}{$\mathrm{R}$} \\
\hline 50 & $0.0369^{\mathrm{aA}}$ & $0.0307^{\mathrm{dB}}$ & $0.0588^{\mathrm{aA}}$ & $0.0552^{\text {bB }}$ \\
\hline 128 & $0.0367^{\mathrm{aA}}$ & $0.0344^{\mathrm{cB}}$ & $0.0509^{\mathrm{bB}}$ & $0.0555^{\mathrm{bA}}$ \\
\hline 288 & $0.0340^{\mathrm{bB}}$ & $0.0423^{\mathrm{aA}}$ & $0.0505^{\mathrm{bA}}$ & $0.0502^{\mathrm{cA}}$ \\
\hline 512 & $0.0280^{\mathrm{cB}}$ & $0.0381^{\mathrm{bA}}$ & $0.0481^{\mathrm{cB}}$ & $0.0575^{\mathrm{aA}}$ \\
\hline \multicolumn{5}{|l|}{ SR } \\
\hline 50 & $0.0400^{\mathrm{aA}}$ & $0.0281^{\mathrm{bB}}$ & $0.0586^{\mathrm{aA}}$ & $0.0531^{\mathrm{cB}}$ \\
\hline 128 & $0.0352^{\mathrm{bA}}$ & $0.0296^{\mathrm{bB}}$ & $0.0569^{\mathrm{bA}}$ & $0.0440^{\mathrm{dB}}$ \\
\hline 288 & $0.0320^{\mathrm{cB}}$ & $0.0373^{\mathrm{aA}}$ & $0.0560^{\mathrm{bB}}$ & $0.0637^{\mathrm{aA}}$ \\
\hline 512 & $0.0258^{\mathrm{dB}}$ & $0.0370^{\mathrm{aA}}$ & $0.0558^{\mathrm{bB}}$ & $0.0612^{\mathrm{bA}}$ \\
\hline
\end{tabular}

$\left(\mathrm{cm}^{2}\right.$ plant $\left.^{-1}\right)$ or explained through the RLAE. The highest total leaf area at the end of the field experiment was achieved by control plants germinated in 50-plug cell tray ${ }^{1}$ and grown in Sphagnum maguellanicum-river wasteperlite growing medium at pot cropping, in agreement with our previous reports (De Lojo et al., 2017, 2019a, 2019b). Plants sprayed with BAP at nursery increased their total leaf area in 128- and 288-plug cell trays at pre and posttransplant to a field bed (Figure 1). In this way, the higher the RLAE, the higher the total leaf area at the end of our field experiment (Table 4).

The higher the plug cell volume during nursery, the higher the number of stems at the end of the field experiment in control plants, although the growing quality used during nursery or pot growth significantly changed this response. In the same way, a BAP spray at nursery increased the stem number per plant in most treatments. Plants from 50-plug cell volume showed small but non-significant differences from control plants (Figure 2).

Total FW at the end of the field experiment showed a response pattern similar to that of total leaf area: it was higher in plants from 50-plug cell tray ${ }^{-1}$ and decreased as the number of cells tray ${ }^{-1}$ increased, in all growing media tested. The growing media significantly changed the posttransplant biomass accumulation on a FW basis during both the pre and the post-transplant stage, especially during nursery (Figure 1). A single BAP spray at nursery when the first true leaf pair was developed significantly increased field FW 120 days later in most of the plug cell volumes and growing media tested during both nursery and pot growth (Figure 3). These results are in agreement with our previous reports (Gandolfo et al., 2016; De Lojo et al., 2017, 2019a, 2019b). The results in different growing media would be related to total and air-filled porosity, as well as container capacity, as previously reported.

The increase in size of a bedding plant depends on the environmental conditions and cultural pot production management. In this regard, although organ size and shape can be modified by environmental factors, the growth of plant organs is under genetic control. At the same time, the genotype sets the limits within which such modification of growth and development can occur. Hakim et al. (2017) indicated that the variation in quality parameters such as plant size during post-production depends on the genotype, as well as on the potting media during the pre-production stage. Our present results, which show that plant size significantly increased under a decrease in soil root restriction, are in agreement with our previous reports, and our FW results (Figure 3) are in agreement with the results of Hakim et al (2017).

As aforementioned, a central trait of a bedding plant is a high compactness, which implies a lower apical dominance as a consequence of a high leaf area per stem and a high stem number (Bergstrand, 2017). Although the ideal habit in the Impatiens genus is subjective and environmentally dependent, at the end of our field experiment, I. walleriana plants showed different stem number (Figure 2) in response to the early previous treatments during nursery and pot cropping. These results make clear that the growers' choice on plug cell volume, growing media in each growth stage, and an exogenous cytokinin spray significantly affect field performance. A secondary benefit of additional branching is a higher number of flowering nodes, which, in turn, increase the number of growing tips for flower primordium initiation. between treatments. Regarding this, Figure 3 shows a positive relationship between flower number and total DW at the end of the field experiment (60 days from transplant), with significant differences.

Although plants from different plug cell volumes, growing media or BAP-spray application during nursery had different sizes at the beginning of the field experiment, the RGR was significantly different between pre-transplant treatments, with results similar to those observed for $\mathrm{FW}$, leaf area or stem 
-Control $\square$ BAP

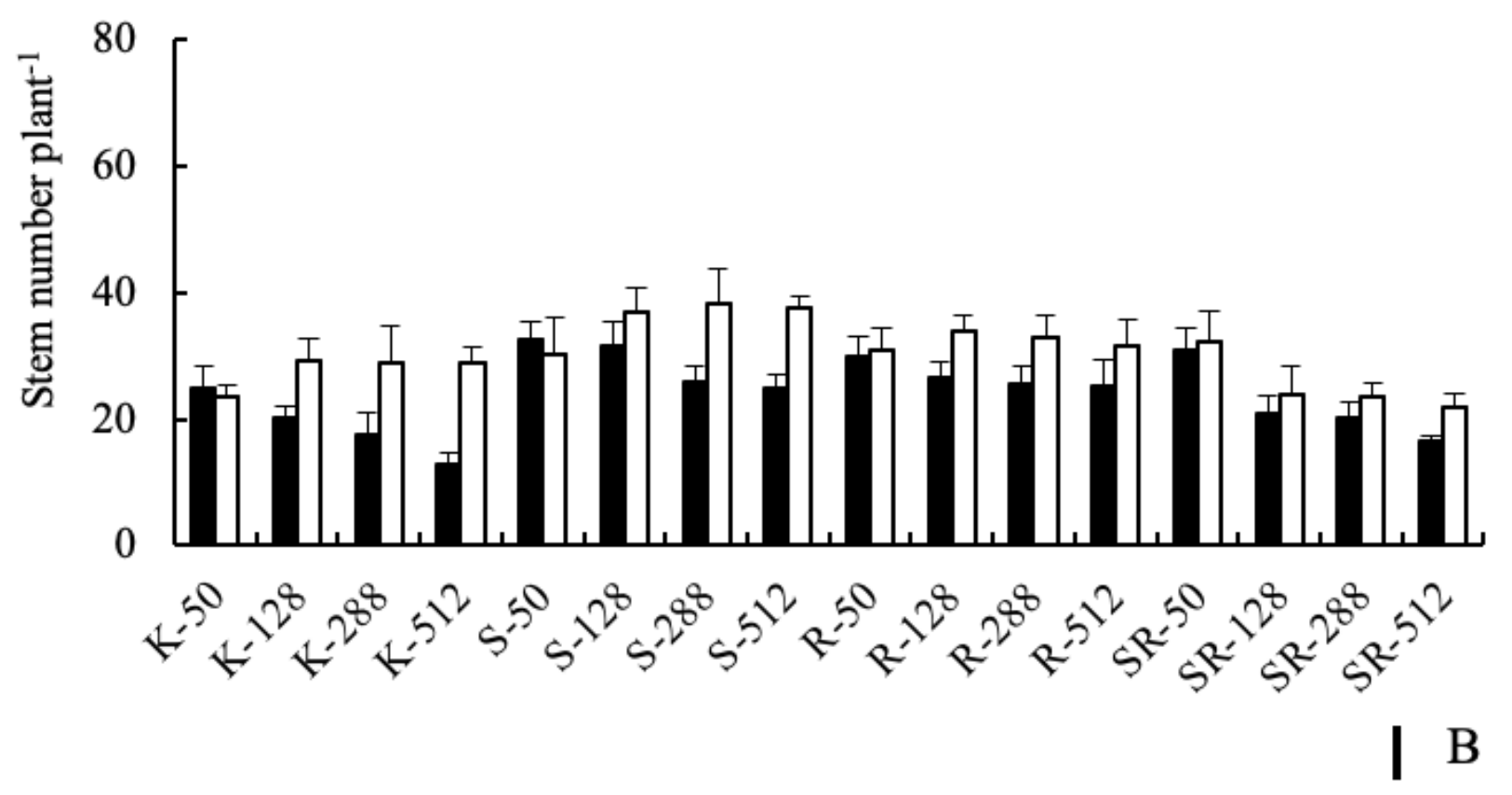

aControl aBAP

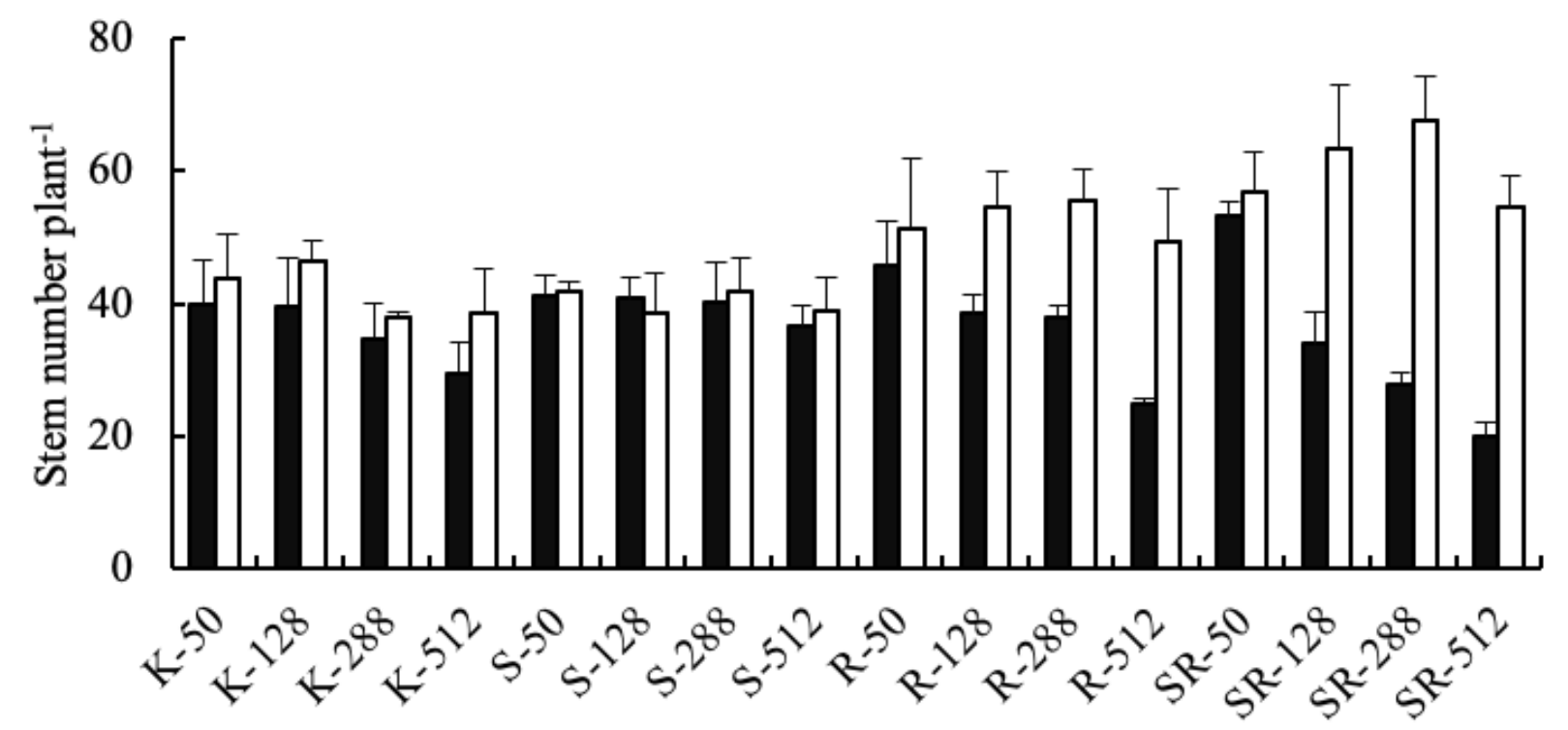

Figure 2. Stem number at the end of the field experiments (60 days after transplanting to a field bed) for Impatiens walleriana plants from four plug cell volumes (50-, 128-, 288-, and 512-cell tray $\left.{ }^{-1}\right)$, four growing media at (A) the nursery or (B) pot stage and sprayed with $100 \mathrm{mg} \mathrm{L}^{-1}$ BAP during nursery. The bars indicate standard errors and the vertical lines indicate least significant differences (LSD). For substrate abbreviations, see Table 1.

number. RGR results can be explained by the NAR observed during the experiment (Table 5). When plotting the data shown in Table 3, we found a close direct relationship between RGR and NAR for both control and BAP-sprayed plants (Figure 4), which suggest that RGR is mainly associated to plant photosynthetic capacity (estimated through NAR).

All the aesthetic traits needed for a commercially successful result must be supported by biomass accumulation on a DW basis using RGR (Joshi et al., 2018). Changes in total leaf area are mainly related to the ability of the shoot apical meristem to initiate and expand leaf primordia, which, in turn, lead to a subsequent increase in the photosynthetic area. Although leaf area determines the ability of a plant to intercept light, DW biomass accumulation is greatly influenced by photosynthetic efficiency, which can be estimated through NAR. Li et al. 
-Control 口BAP

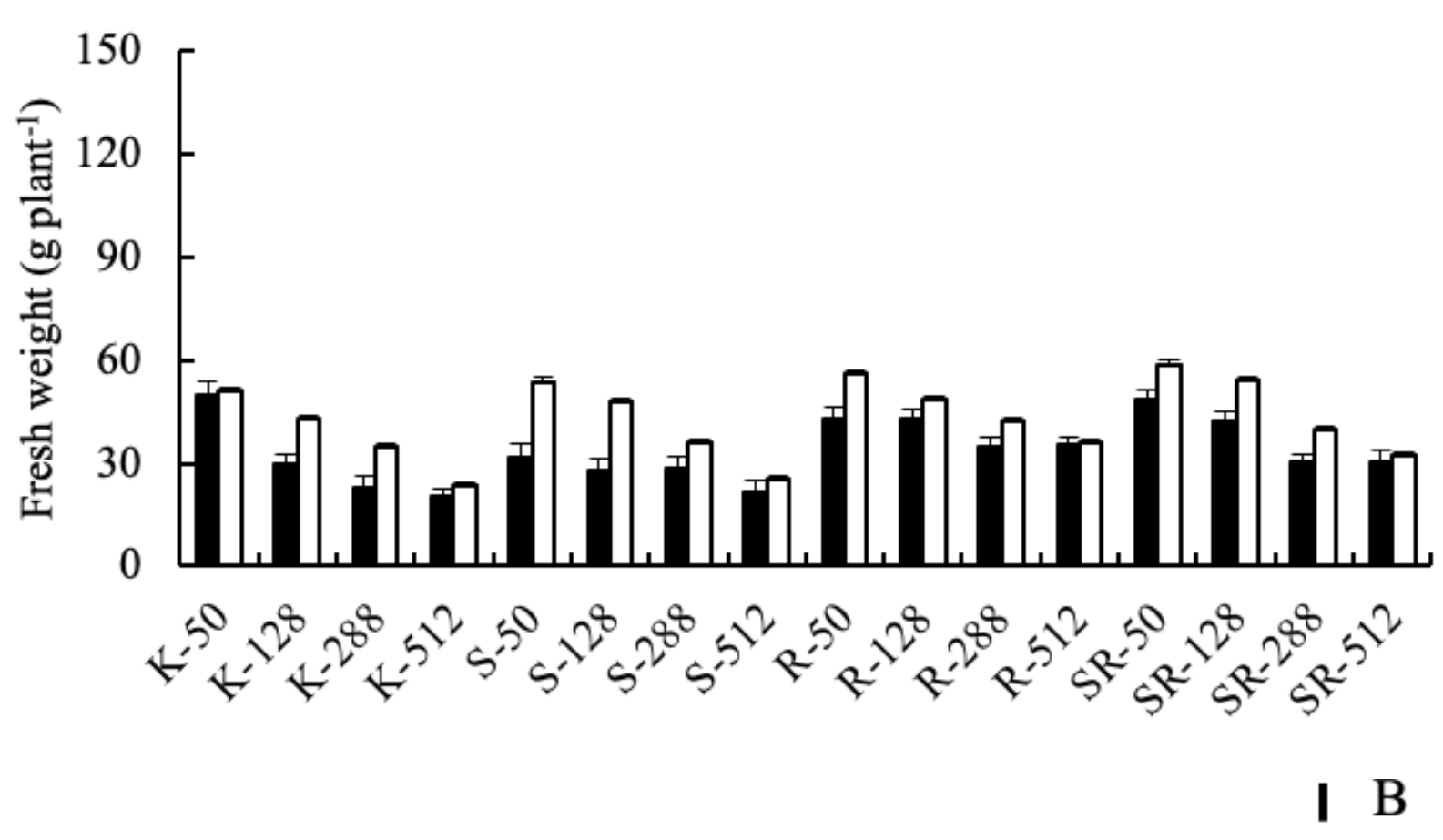

口Control 口BAP

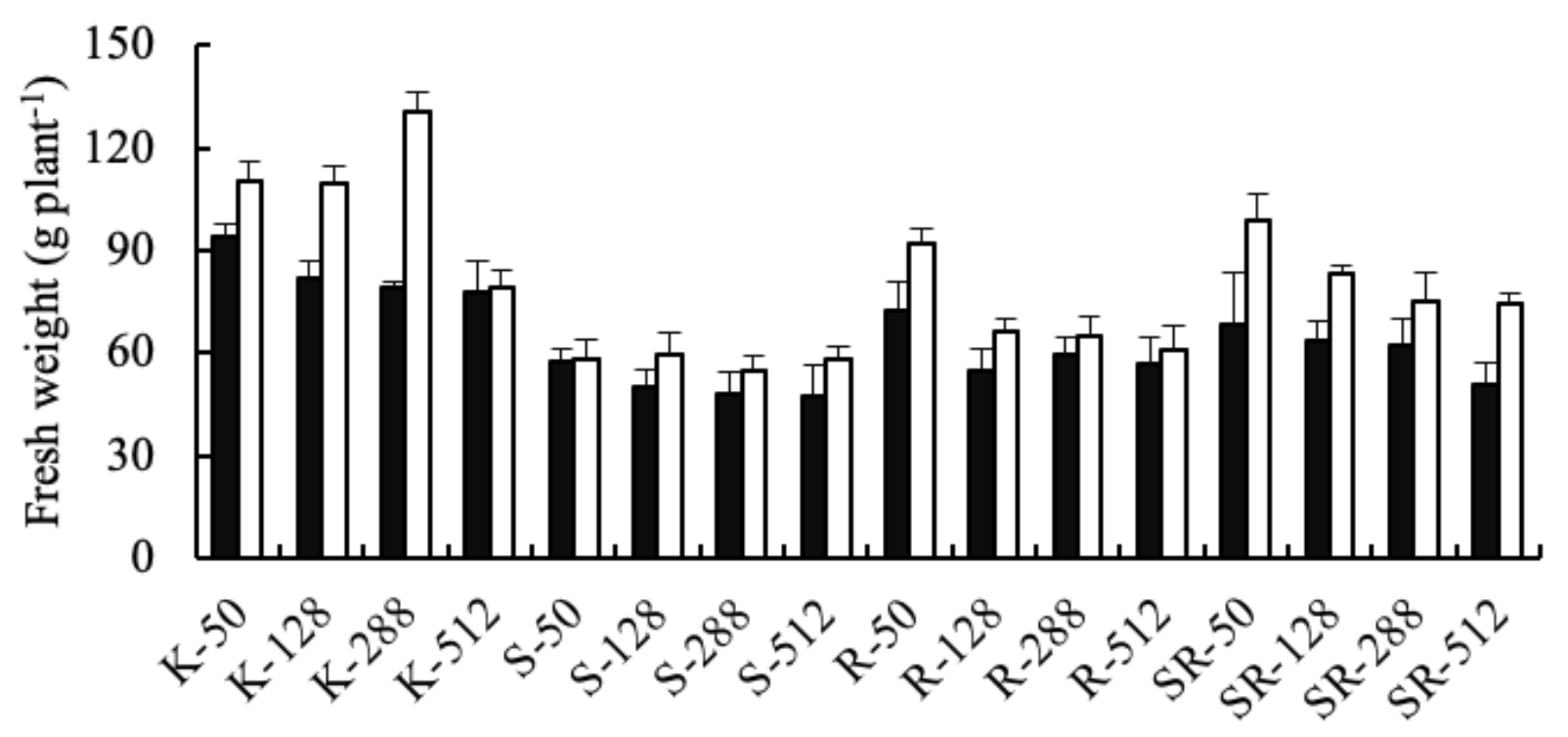

Figure 3. Total fresh weight at the end of the field experiment (60 days after transplanting to a field bed) for Impatiens walleriana plants from four plug cell volumes (50-, 128-, 288-, and 512-cell tray ${ }^{-1}$ ), four growing media at (A) the nursery or (B) pot stage and sprayed with $100 \mathrm{mg} \mathrm{L}^{-1}$ BAP during nursery. The bars indicate standard errors and the vertical lines indicate least significant differences (LSD). For substrate abbreviations, see Table 1.

(2016) indicated that, in general, NAR is the best general predictor of the variation in RGR, in agreement with our results (Table 5 and Figure 4). Root restrictions often depress photosynthetic capacity (Zakaria et al., 2020) and decrease energy synthesis. The positive relationships here found between NAR and RGR (Figure 4A) are in agreement with these previous reports.
When we analyzed the relative DW accumulation between the end of the pot cropping cycle and the field experiment, we found that plants from different nursery or pot growing media showed an inverse response. The plants grown in the four different growing media during nursery, but in Klasmann ${ }^{\circledR}$ growing medium during the pot cropping, decreased their DW at the end of the field experiment. The lower the plug 
cell volume, the lower the relative DW. BAP-sprayed plants showed higher DW losses (Figure 5A). Quite the opposite was found when plants grown in Klasmann ${ }^{\circledast}$ growth medium during nursery were transplanted to four different growing media in the pot, before being transplanted to the field. These plants showed a positive DW gain, although differences were seen according to the nursery plug cell volume and BAP treatment (Figure 5B). Data and physiological mechanisms involved are in agreement with previous reports (De Lojo et al., 2017, 2019a, 2019b; Di Benedetto et al., 2020).

The shoot reducing sugars at the end of the field experiment showed results similar to those for FW, DW, and leaf area, and were affected by the growing media, the plug cell volume and BAP (Figure 6). Sugar production in different environmental conditions determine the growth and stress response. Biswal et al. (2011) indicated that, in addition to its role as a major source of energy, sugar acts as a signaling molecule. However, cellular sugar signaling must be integrated with other growth regulatory pathways, such as phytohormone signaling (Lastdrager et al., 2014).

The number of flowers developed during the field experiment was significantly related to plug cell volume during nursery, the growing media before transplant, and the BAP application (Figures 7A and 7B). When data was plotted together, we found a close direct relationship $\left(\mathrm{r}^{2}=0.688\right)$ between flower production and total DW at the end of the field experiment (Figure 7C).

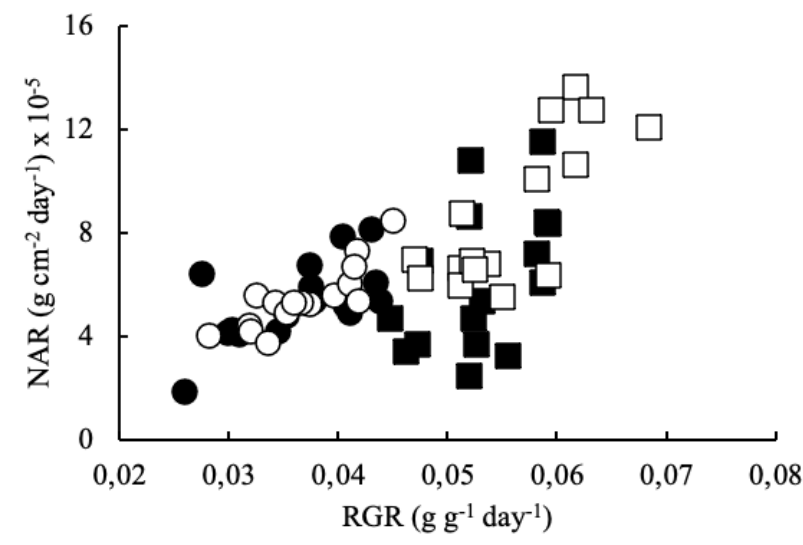

-Pre-Control OPre-BAP $\square$ Post-Control $\square$ Post-BAP

Figure 4. Relationships between net assimilation rate (NAR) and relative growth rate (RGR) according to four pretransplant plug cell volumes (50-, 128-, 288-, and 512-cell tray $^{-1}$ ), four growing media at the pre and post-pot transplant and spraying with zero (control plants, empty symbols) or

$100 \mathrm{mg} \mathrm{L}^{-1} \mathrm{BAP}$ (full symbols) at the pre-pot transplant stage. For substrate abbreviations, see Table 1. The straightline regressions were: $\mathrm{NAR}_{\text {Pre-Control }}=165.42 \mathrm{RGR}-0.62\left(\mathrm{r}^{2}=\right.$ $0.684), \mathrm{NAR}_{\text {Pre-BAP }}=220.21 \mathrm{RGR}-2.59\left(\mathrm{r}^{2}=0.705\right), \mathrm{NAR}_{\text {Post- }}$ Control $=269.62$ RGR - $8.08\left(\mathrm{r}^{2}=0.623\right)$, and $\mathrm{NAR}_{\text {Post-BAP }}=365.97$ RGR - $11.72\left(\mathrm{r}^{2}=0.602\right)$. Pre: between nursery and pot growth $(\bullet, \circ)$; Post: during field experiment $(\mathbf{\square}, \square)$.

Table 5. Changes in relative growth rate (RGR) and net assimilation rate (NAR) during field-transplant for Impatiens walleriana plants from four plug cell volumes $\left(50-, 128-, 288-\right.$, and 512-cell tray $\left.{ }^{-1}\right)$, four growing media at the nursery or pot stage and sprayed with zero (control plants) or $100 \mathrm{mg} \mathrm{L}^{-1}$ BAP during nursery. Different lowercase letters indicate significant differences $(\mathrm{p}<0.05)$ between pre-transplant plug cell volumes, while different capital letters indicate significant differences $(\mathrm{p}<0.05)$ between pre and post-growing media. For substrate abbreviations, see Table 1 . The probability of the RGR and NAR slopes being zero was $\mathrm{p}<0.001$. Pre: during nursery; Post: between nursery and pot growth.

\begin{tabular}{|c|c|c|c|c|c|c|c|c|}
\hline & \multicolumn{4}{|c|}{ RGR ( g g $^{-1}$ day $\left.^{-1}\right)$} & \multicolumn{4}{|c|}{$\operatorname{NAR}\left(\mathrm{g} \mathrm{cm}^{-2}\right.$ day $\left.^{-1}\right) \times 10^{-5}$} \\
\hline & Pre-Control & Pre-BAP & Post-Control & Post-BAP & Pre-Control & Pre-BAP & Post-Control & Post-BAP \\
\hline \multicolumn{9}{|l|}{$\mathbf{K}$} \\
\hline 50 & $0.0309^{\mathrm{aA}}$ & $0.0282^{\mathrm{cB}}$ & $0.0592^{\mathrm{aB}}$ & $0.0616^{\mathrm{bA}}$ & $6.46^{\mathrm{aA}}$ & $4.08^{\mathrm{dB}}$ & $8.39^{\mathrm{aB}}$ & $13.67^{\mathrm{aA}}$ \\
\hline 128 & $0.0299^{\mathrm{aB}}$ & $0.0318^{\mathrm{bA}}$ & $0.0587^{\mathrm{aB}}$ & $0.0683^{\mathrm{aA}}$ & $4.11^{\mathrm{bB}}$ & $4.43^{\mathrm{cA}}$ & $7.24^{\mathrm{bB}}$ & $12.10^{\mathrm{cA}}$ \\
\hline 288 & $0.0275^{\mathrm{bB}}$ & $0.0325^{\mathrm{bA}}$ & $0.0581^{\mathrm{aA}}$ & $0.0581^{\mathrm{cA}}$ & $4.17^{\mathrm{bB}}$ & $5.59^{\mathrm{aA}}$ & $6.12^{\mathrm{cB}}$ & $12.75^{\mathrm{bA}}$ \\
\hline 512 & $0.0259^{\mathrm{cB}}$ & $0.0342^{\mathrm{aA}}$ & $0.0523^{\mathrm{bB}}$ & $0.0594^{\mathrm{cA}}$ & $1.88^{\mathrm{cB}}$ & $5.33^{\mathrm{bA}}$ & $4.71^{\mathrm{dB}}$ & $10.10^{\mathrm{dA}}$ \\
\hline \multicolumn{9}{|l|}{$\mathbf{S}$} \\
\hline 50 & $0.0410^{\mathrm{aA}}$ & $0.0320^{\mathrm{dB}}$ & $0.0590^{\mathrm{aA}}$ & $0.0470^{\mathrm{dB}}$ & $5.96^{\mathrm{aA}}$ & $4.24^{\mathrm{dB}}$ & $10.85^{\mathrm{aA}}$ & $10.69^{\mathrm{aA}}$ \\
\hline 128 & $0.0375^{\mathrm{bA}}$ & $0.0374^{\mathrm{cA}}$ & $0.0521^{\mathrm{bB}}$ & $0.0616^{\mathrm{aA}}$ & $4.95^{\mathrm{bB}}$ & $5.28^{\mathrm{cA}}$ & $8.45^{\mathrm{bA}}$ & $7.01^{\mathrm{bB}}$ \\
\hline 288 & $0.0352^{\mathrm{cB}}$ & $0.0417^{\mathrm{aA}}$ & $0.0472^{\mathrm{cA}}$ & $0.0549^{\mathrm{cB}}$ & $4.84^{\mathrm{aB}}$ & $7.35^{\mathrm{aA}}$ & $4.72^{\mathrm{cB}}$ & $5.56^{\mathrm{dA}}$ \\
\hline 512 & $0.0345^{\mathrm{cB}}$ & $0.0396^{\mathrm{bA}}$ & $0.0447^{\mathrm{dB}}$ & $0.0591^{\mathrm{bA}}$ & $4.24^{\mathrm{cB}}$ & $5.63^{\mathrm{bA}}$ & $3.70^{\mathrm{dB}}$ & $6.39^{\mathrm{cA}}$ \\
\hline \multicolumn{9}{|l|}{$\mathbf{R}$} \\
\hline 50 & $0.0438^{\mathrm{aA}}$ & $0.0352^{\mathrm{cB}}$ & $0.0531^{\mathrm{aA}}$ & $0.0475^{\mathrm{cB}}$ & $6.12^{\mathrm{aA}}$ & $4.93^{\mathrm{dB}}$ & $8.64^{\mathrm{aA}}$ & $6.25^{\mathrm{bB}}$ \\
\hline 128 & $0.0434^{\mathrm{aA}}$ & $0.0410^{\mathrm{bB}}$ & $0.0520^{\mathrm{aA}}$ & $0.0511^{\mathrm{bA}}$ & $5.39^{\mathrm{bB}}$ & $6.06^{\mathrm{cA}}$ & $5.40^{\mathrm{bB}}$ & $6.02^{\mathrm{bA}}$ \\
\hline 288 & $0.0407^{\mathrm{bB}}$ & $0.0450^{\mathrm{aA}}$ & $0.0519^{\mathrm{aA}}$ & $0.0511^{\mathrm{bA}}$ & $5.40^{\mathrm{bB}}$ & $6.73^{\mathrm{bA}}$ & $3.45^{\mathrm{cB}}$ & $6.65^{\mathrm{aA}}$ \\
\hline 512 & $0.0377^{\mathrm{cB}}$ & $0.0414^{\mathrm{bA}}$ & $0.0462^{\mathrm{bB}}$ & $0.0537^{\mathrm{aA}}$ & $5.23^{\mathrm{cB}}$ & $8.49^{\mathrm{aA}}$ & $2.47^{\mathrm{dB}}$ & $6.83^{\mathrm{aA}}$ \\
\hline \multicolumn{9}{|l|}{ SR } \\
\hline 50 & $0.0430^{\mathrm{aA}}$ & $0.0365^{\mathrm{bB}}$ & $0.0587^{\mathrm{aA}}$ & $0.0522^{\mathrm{bB}}$ & $8.16^{\mathrm{aA}}$ & $3.80^{\mathrm{bB}}$ & $11.56^{\mathrm{aA}}$ & $6.92^{\mathrm{cB}}$ \\
\hline 128 & $0.0404^{\mathrm{bA}}$ & $0.0336^{\mathrm{cB}}$ & $0.0555^{\mathrm{bA}}$ & $0.0513^{\mathrm{bB}}$ & $7.86^{\mathrm{bA}}$ & $5.33^{\mathrm{aB}}$ & $6.92^{\mathrm{bA}}$ & $6.63^{\mathrm{dB}}$ \\
\hline 288 & $0.0373^{\mathrm{cA}}$ & $0.0359^{\mathrm{bB}}$ & $0.0526^{\mathrm{cA}}$ & $0.0525^{\mathrm{bA}}$ & $6.80^{\mathrm{cA}}$ & $5.33^{\mathrm{aB}}$ & $3.72^{\mathrm{cB}}$ & $8.78^{\mathrm{bA}}$ \\
\hline 512 & $0.0303^{\mathrm{dB}}$ & $0.0418^{\mathrm{aA}}$ & $0.0475^{\mathrm{dB}}$ & $0.0631^{\mathrm{aA}}$ & $4.27^{\mathrm{dB}}$ & $5.38^{\mathrm{aA}}$ & $3.27^{\mathrm{dB}}$ & $12.77^{\mathrm{aA}}$ \\
\hline
\end{tabular}


-Pre-Control 口Pre-BAP

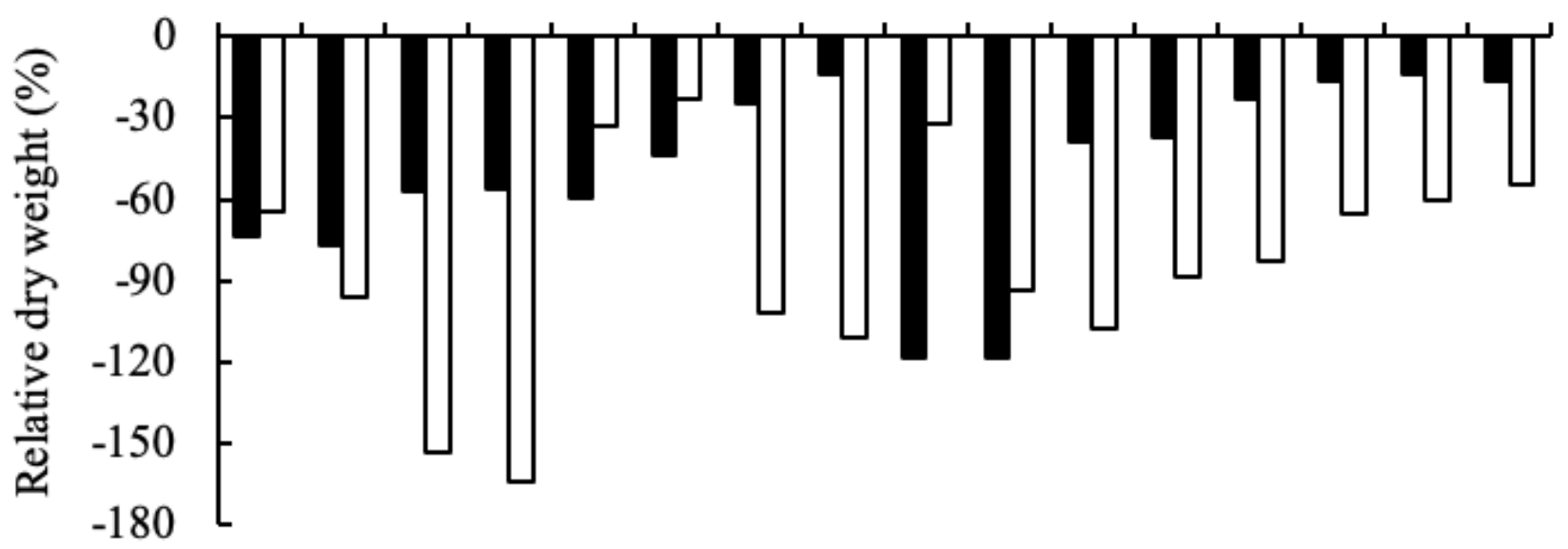

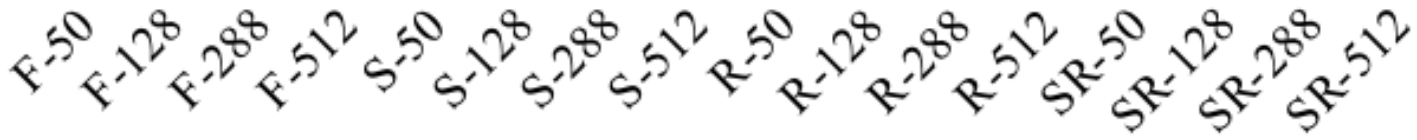

| B

QPost-Control $\square$ Post-BAP

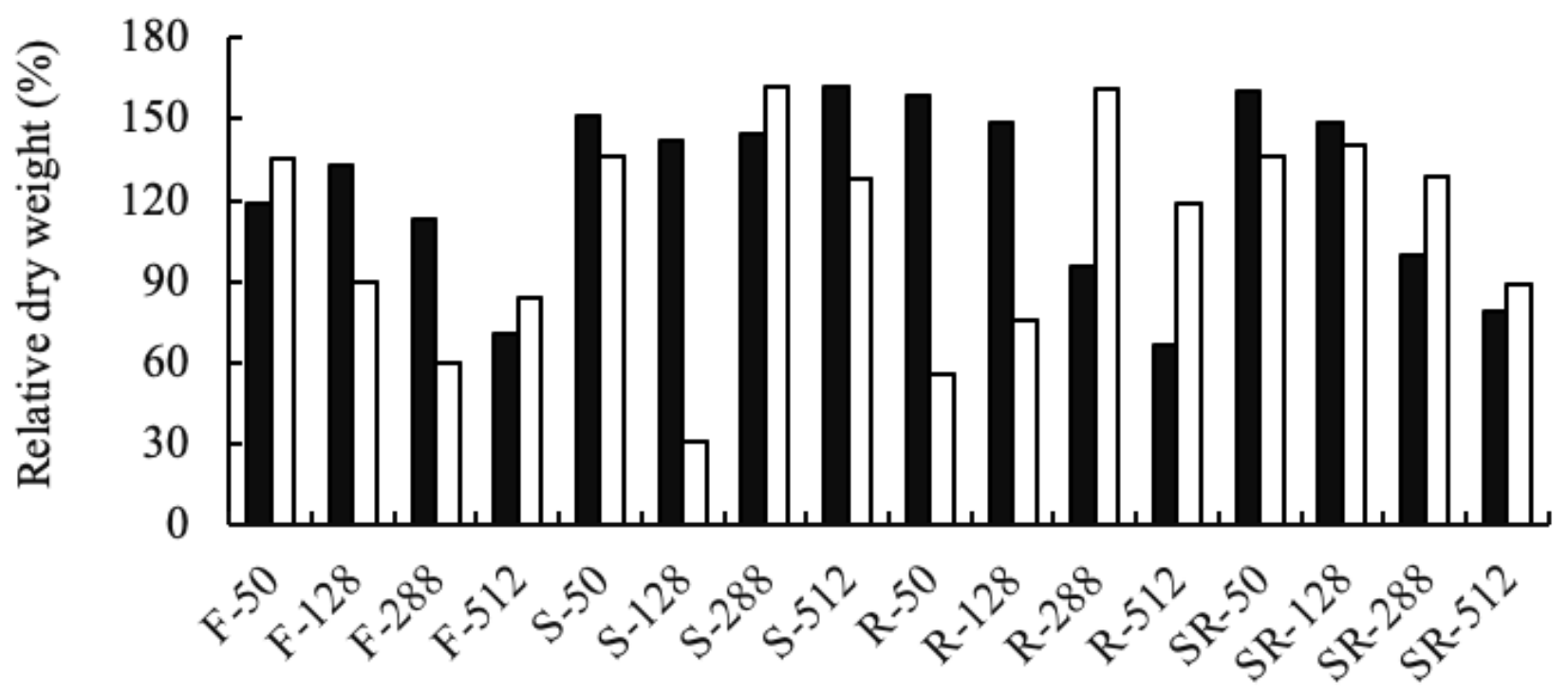

Figure 5. Relative changes in dry weight after transplant to a field bed for 60 days for Impatiens walleriana plants from four plug cell volumes (50-, 128-, 288-, and 512-cell tray $\left.{ }^{-1}\right)$, four growing media at (A) the nursery or (B) pot stage and sprayed with $100 \mathrm{mg} \mathrm{L}^{-1}$ BAP during nursery. The vertical lines indicate least significant differences (LSD). For substrate abbreviations, see Table 1 .

Poorter and Sack (2012) indicated that sink organs can potentially stimulate sugar supply by activating their consumption rate, thereby increasing their sink strength, whereas Feller et al. (2015) reported that the relative carbon allocation to a particular organ must be regarded as a function of the source and sink activities of all parts of the plant regulated by the relative allocation of photo-assimilates.
Regarding this issue, Smith et al. (2018) indicated that the source-sink relationships can be modified by the crop management and environmental factors, including abiotic and biotic stresses, whereas Ma and Wang (2020) reported that changes in the allometric slopes $(\beta)$ reflect variations in carbon partitioning in response to biotic and abiotic environment interactions. The carbohydrate partitioning 
-Control DBAP

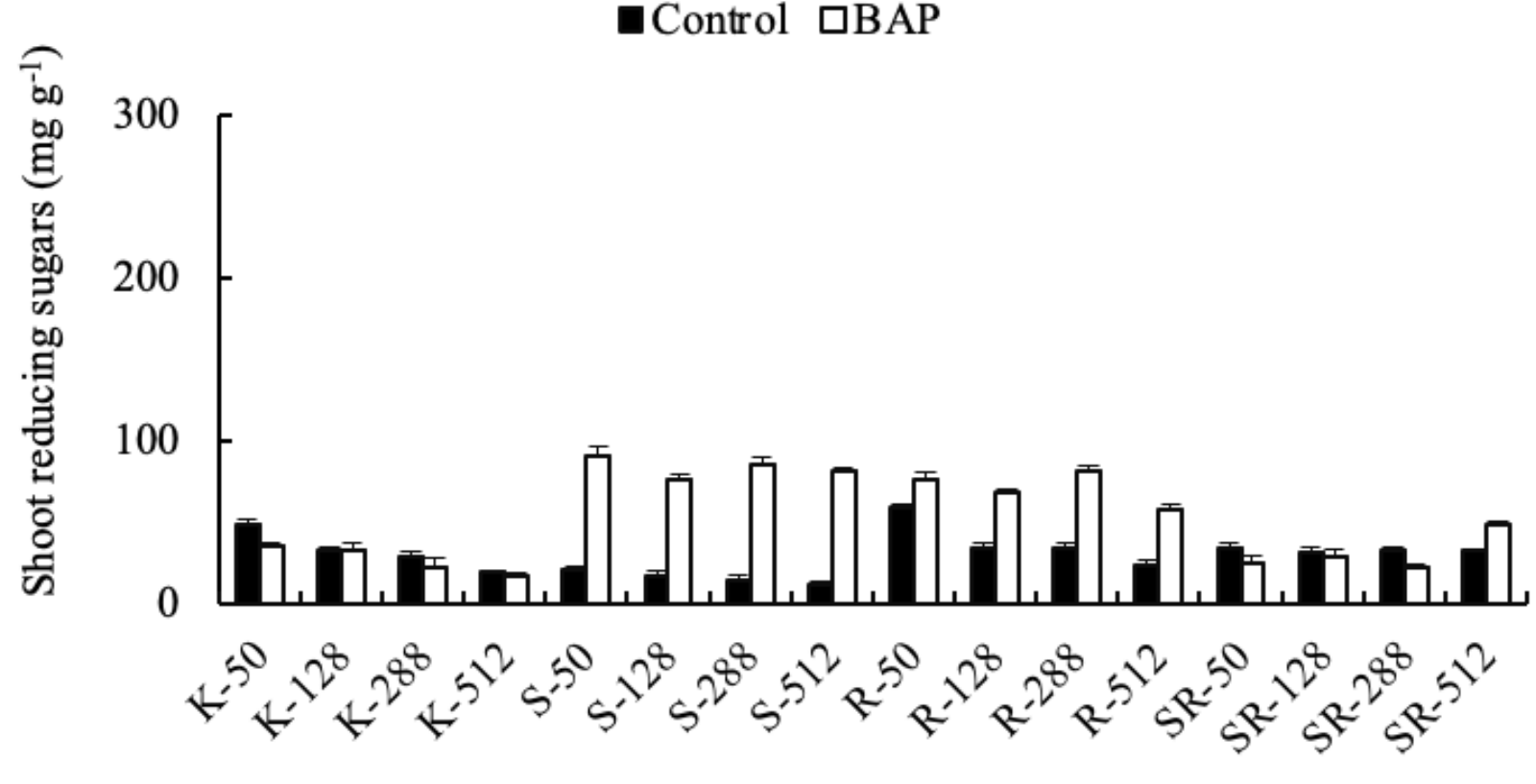

—Control 口BAP

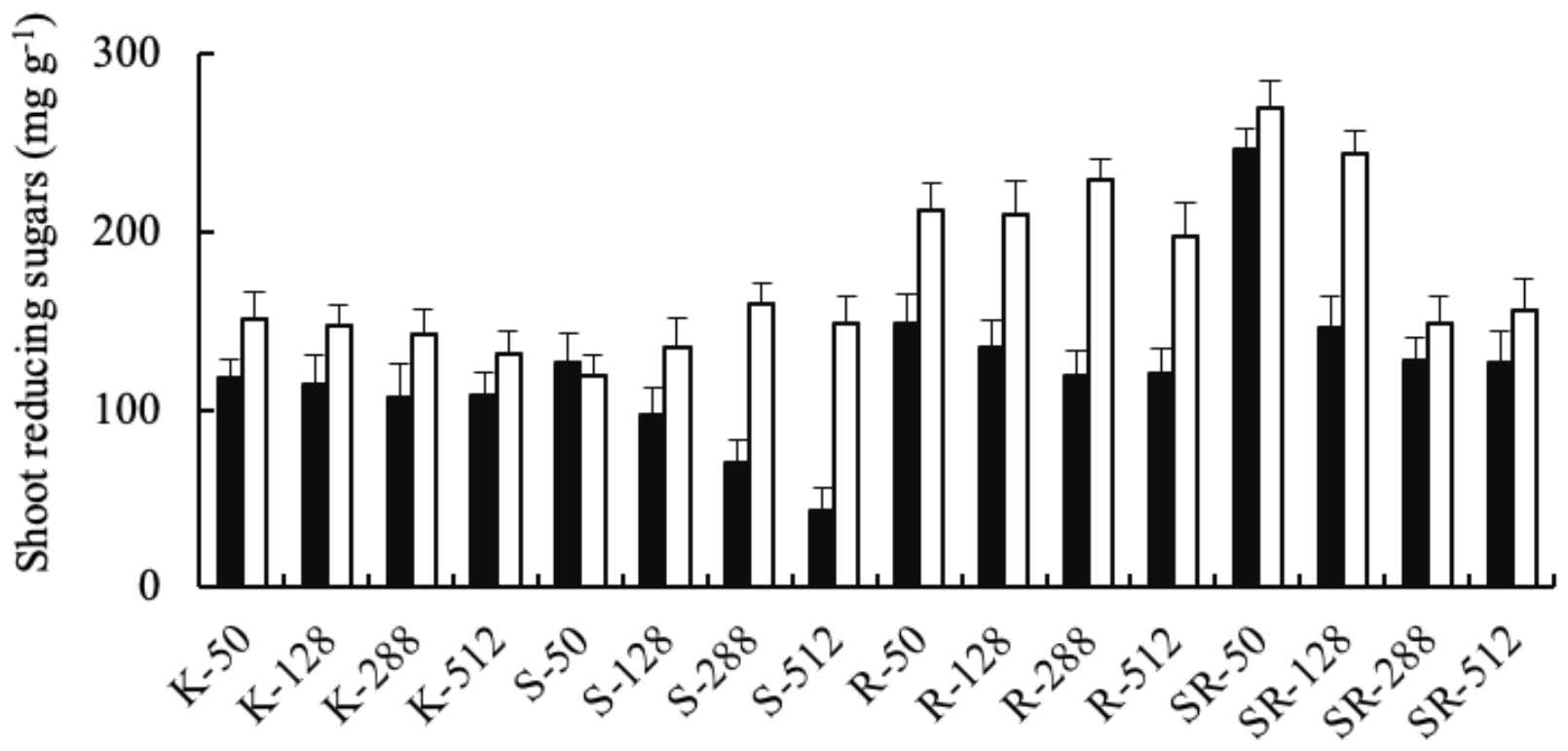

Figure 6. Content of shoot reducing sugars at the end of the experiments (60 days after transplanting to a field bed) for Impatiens walleriana plants from four plug cell volumes (50-, 128-, 288-, and 512-cell tray $\left.{ }^{-1}\right)$, four growing media at (A) the nursery or (B) pot stage and sprayed with zero (control plants) or $100 \mathrm{mg} \mathrm{L}^{-1}$ BAP during nursery. The bars indicate standard errors and the vertical lines indicate least significant differences (LSD). For substrate abbreviations, see Table 1.

between competing sites is explained by the fact that plants are capable of modifying their resource allocation to favor the growth of their growing parts. Previous data from our laboratory have shown a change in the photo-assimilate allocation in $I$. walleriana plants as a result of different relationships between plug cell volume during nursery (De Lojo et al., 2017) and growing medium used during both nursery (De Lojo et al., 2019b) and pot cropping (De Lojo et al., 2019a). During the present field experiments, we found a similar pattern response (data not shown), which explains the results of total reducing sugars shown in Figure 6.

At the beginning of the field experiments, the small plant size was not the only result of the different stresses suffered by the plants during nursery and pot cropping; plant DW accumulation performance in the field was also significantly different (Tables 2 and 3). Our results showed an inverse DW accumulation in plants grown in different growing media during nursery or pot culture at 
-Control 口BAP

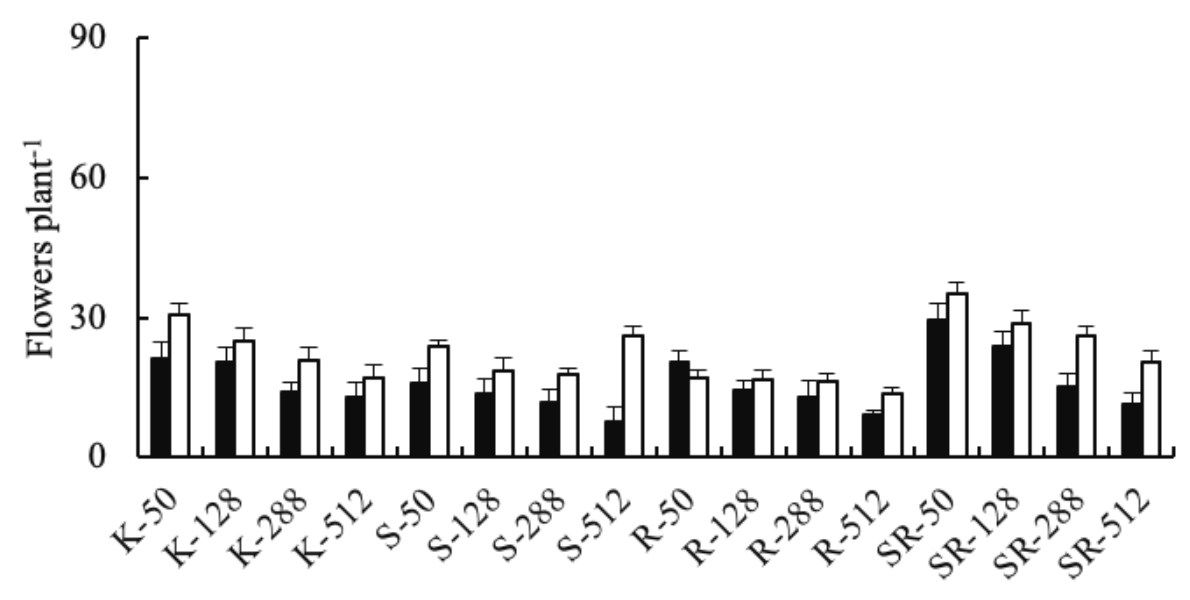

| B

-Control 口BAP

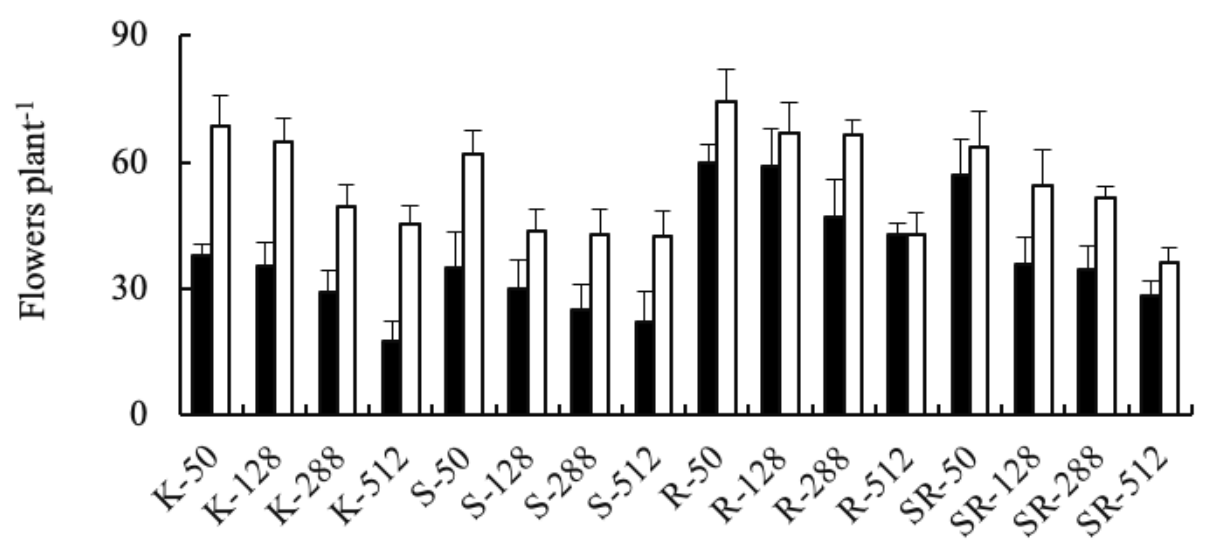

$\mathrm{C}$

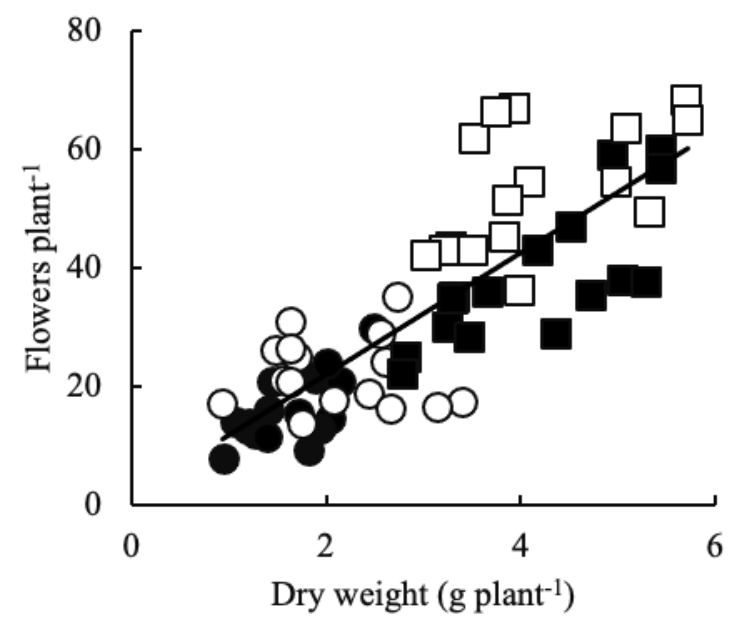

Figure 7. Flower number at the end of the experiments ( 60 days after transplanting to a field bed) for Impatiens walleriana plants from four plug cell volumes (50-, 128-, 288-, and 512-cell tray $\left.{ }^{-1}\right)$, four growing media at (A) the nursery or (B) pot stage and sprayed with zero (control plants) or $100 \mathrm{mg} \mathrm{L}^{-1} \mathrm{BAP}$ during nursery. The bars indicate standard errors and the vertical lines indicate least significant differences (LSD). For substrate abbreviations, see Table 1. Pre: during nursery $(\bullet, \circ)$; Post: between nursery and pot growth $(\boldsymbol{\bullet}, \square)$. Plate C: relationships between flower number per plant and total dry weight. The straight-line regressions were: Flowers $=10.30$ Dry weight +1.39 $\left(r^{2}=0.688\right)$. Control plants (full symbols) and BAP-sprayed plants (empty symbols) are indicated. 
the end of field experiments (Figure 5). This data shows a performance that is not easy to see when bedding plants are transplanted to field environments, but is decisive to quantify traits related to shelf life, such as flower production and flower length. Figure 7 shows a direct relationship between flower production and DW at the end of the field experiment, with significant differences between treatments at both nursery and pot cropping (data not shown). Despite the significant importance of flower longevity in I. walleriana breeding programs (De, 2017), the effect of technological stress sources on field performance has been scarcely explored.

The novelty of the present results is that they show that plant quality and garden performance are dependent on the plug cell size during nursery and the growing medium quality during both nursery and pot culture, which must, thus, be considered as abiotic pre-transplant stresses for a garden post-production self-life. These results lead to the conclusion that, from the grower's point of view, increasing nursery yield (by decreasing plug cell volume) or reducing costs (by using lower growing medium quality) can constitute a bad choice when the consumers of $I$. walleriana bedding plants identify that their product has a lower shelf-life field performance.

\section{Conclusions}

The hypothesis tested was that the abiotic stresses imposed by the plug cell volume and growing medium quality constitute interactive processes associated with the root system size and, presumably, with root cytokinin synthesis, both of which affect the biomass accumulation and useful life of I. walleriana during its post-production in the field. Our results validate these hypotheses.

\section{Author contribution}

JDL: Conceptualization, Data Curation. EG: Conceptualization, Data Curation, Formal Analysis, Supervision, Writing-original draft. VF: Conceptualization, Data Curation.

EBG: Formal Analysis, Supervision, Writing - original draft. CLB: Formal Analysis, Supervision, Writing original draft. AB: Formal Analysis, Supervision, Writing - original draft.

\section{Acknowledgments}

This work was part of a Magister thesis by J. De Lojo at the University of Buenos Aires, supported by the University of Buenos Aires Science Program 2014-2017 (Q322) and 2018-2021 (145BA), Argentine.

\section{References}

ARMITAGE, A.M. Influence of production practices on postproduction life of bedding plants. Acta Horticulturae, v.21, p.269-277, 1986. https://doi.org/10.17660/ ActaHortic.1986.181.34
BARRETT, G.E.; ALEXANDER, P.D.; ROBINSON, J.S.; BRAGG, N.C. Achieving environmentally sustainable growing media for soilless plant cultivation systems. A review. Scientia Horticulturae, v.212, p.220-234, 2016. https://doi.org/10.1016/j.scienta.2016.09.030

BERGSTRAND, K.J.I. Methods for growth regulation of greenhouse produced ornamental pot-and bedding plants-a current review. Folia Horticulturae, v.29, n.1, p.63-74, 2017. https://doi.org/10.1515/fhort-2017-0007

BISWAL, B.; JOSHI, P.N.; RAVAL, M.K.; BISWAL, U.C. Photosynthesis, a global sensor of environmental stress in green plants: stress signaling and adaptation. Current Science, v.101, n.1, p.47-56, 2011.

DE, L. Improvement of ornamental plants-A review. International Journal of Horticulture, v.7, n.22, 2017. https://doi.org/10.5376/ijh.2017.07.0022

DE LOJO, J.; GANDOLFO, E.; GIARDINA, E.; BOSCHI, C.; DI BENEDETTO, A. Growing media quality and plug cell volume would be interactive abiotic stresses for Impatiens walleriana pot yield. Asian Journal of Agricultural and Horticultural Research, v.4, n.1, p.1-14, 2019a. https://doi.org/10.9734/AJAHR/2019/ v4i130008

DE LOJO, J.; GANDOLFO, E.; GIARDINA, E.; BOSCHI, C.; DI BENEDETTO, A. Pot cell volume, growing media quality and benzyl aminopurine (BAP) spray effects for nursery growth of Impatiens walleriana. International Journal of Plant Soil Science, v.27, n.6, p.1-13, 2019 b. https://doi.org/10.9734/IJPSS/2019/v27i630091

DE LOJO, J.; GANDOLFO, E.; GÓMEZ, D.; FEURING, V.; MONTI, S.; GIARDINA, E.; BOSCHI, C.; DI BENEDETTO, A. Root restriction effects on the bedding pot plant Impatiens walleriana. Journal of Experimental Agriculture International, v.15, n.4, p.1-16, 2017. https:// doi.org/10.9734/JEAI/2017/31997

DI BENEDETTO, A.; GIARDINA, E.; DE LOJO, J.; GANDOLFO, E.; HAKIM, G. Exogenous benzyl amino purine (BAP) applications for the ornamental pot industry. KORTESMÄKI, S. Cytokinins: Biosynthesis and Uses. New York: Nova Science Publishers, 2020. p.1-56.

DI BENEDETTO, A.; PAGANI, A. Dry weight accumulation in the Impatiens walleriana pot plant in responses to different pre-transplant plug cell volume. European Journal of Horticultural Science, v.78, n.2, p.76-85, 2013.

FELLER, C.; FAVRE, P.; JANKA, A.; ZEEMAN, S.C.; GABRIEL, J.P.; REINHARDT, D. Mathematical modeling of the dynamics of shoot-root interactions and resource partitioning in plant growth. PloS One, v.10, n.7, e0127905, 2015. https://doi.org/10.1371/journal.pone.0127905 
FERRANTE, A.; TRIVELLINI, A.; SCUDERI, D.; ROMANO, D.; VERNIERI, P. Post-production physiology and handling of ornamental potted plants. Postharvest Biology and Technology, v.100, p.99-108, 2015. https:// doi.org/ 10.1016/j.postharvbio.2014.09.005

FONTENO, W.C. Growing media types and physical/ chemical properties. REED, D.W. Water, Media and Nutrition for Greenhouse Crops: A Grower's Guide. Batavia: Ball Publishing, 1996.

GANDOLFO, E.; HAKIM, G.; GERACI, J.; FEURING, V.; GIARDINA, E.; DI BENEDETTO, A. Responses of pansy (Viola wittrockiana Gams.) to the quality of the growing media. American Journal of Experimental Agriculture, v.12, n.3, p.1-10, 2016. https://doi.org/10.9734/AJEA/2016/26144

HAKIM, G.; GANDOLFO, E.; GIARDINA, E.; DI BENEDETTO, A. The effect of the pre-transplant pot media quality on pansy garden performance. International Journal of Plant Soil Science, v.19, n.4, p.1-12, 2017. https://doi.org/ 10.9734/IJPSS/2017/36877

JOSHI, R.; SINGLA-PAREEK, S.L.; PAREEK, A. Engineering abiotic stress response in plants for biomass production. Journal of Biological Chemistry, v.293, n.14, p.5035-5043, 2018. https://doi.org/10.1074/jbc. TM117.000232

LASTDRAGER, J.; HANSON, J.; SMEEKENS, S. Sugar signals and the control of plant growth and development. Journal of Experimental Botany, v.65, n.3, p.799-807, 2014. https://doi.org/10.1093/jxb/ert474

LI, X.; SCHMID, B.; WANG, F.; PAINE, C.T. Net assimilation rate determines the growth rates of 14 species of subtropical forest trees. PloS One, v.11, n.3, e0150644, 2016. https://doi.org/10.1371/journal.pone.0150644
MA, X.Z.; WANG, X.P. Biomass partitioning and allometric relations of the Reaumuria soongorica shrub in Alxa steppe desert in NW China. Forest Ecology Management, v.468, p.118178, 2020. https://doi.org/10.1016/j. foreco.2020.118178

POORTER, H.; SACK, L. Pitfalls and possibilities in the analysis of biomass allocation patterns in plants. Frontiers in Plant Science, v.3, p.259, 2012. https://doi.org/10.3389/ fpls.2012.00259

RAHELIVOLOLONA, E.M.; FISCHER, E.; JANSSENS, S.B.; RAZAFIMANDIMBISON, S.G. Phylogeny, infrageneric classification and species delimitation in the Malagasy Impatiens (Balsaminaceae). PhytoKeys, v.110, p.51-67, 2018. https://doi.org/10.3897/ phytokeys. 110.28216

SMITH, M.R.; RAO, I.M.; MERCHANT, A. Sourcesink relationships in crop plants and their influence on yield development and nutritional quality. Frontiers in Plant Science, v.9, p.1889, 2018. https://doi.org/10.3389/ fpls.2018.01889

STYER, R.C.; KORANSKI, D.S. Plug and transplant production. A grower's Guide. Batavia: Ball Publishing, 1997.

UCHNEAT, M.S. Impatiens wallerana. ANDERSON, N.O. Flower breeding and genetics issues, challenges and opportunities for the 21st Century. St. Paul: University of Minnesota, 2007. p.277-301.

ZAKARIA, N.I.; ISMAIL, M.R.; AWANG, Y.; MEGAT WAHAB, P.E.; BERAHIM, Z. Effect of root restriction on the growth, photosynthesis rate, and source and sink relationship of Chilli (Capsicum annuum L.) grown in soilless culture. BioMed Research International, v.2020, 2706937. https://doi.org/10.1155/2020/2706937 